John Carroll University

Carroll Collected

2020

Monitoring the accounting profession under the AICPA Code of

Professional Conduct: An analysis of state board of accountancy participation

J. Gregory Jenkins

Velina Popova

Mark D. Sheldon

Follow this and additional works at: https://collected.jcu.edu/fac_bib_2020

Part of the Accounting Commons 


\section{Monitoring the accounting profession under the AICPA code of professional conduct: An analysis of state board of accountancy participation}

Keywords:

AICPA code of professional conduct CPC violation reporting

Monitoring CPA misconduct

Code of professional conduct adoption

State boards of accountancy

\begin{abstract}
A B S T R A C T
We study state board of accountancy participation in monitoring the conduct of accounting professionals under the American Institute of Certified Public Accountants' (AICPA) Code of Professional Conduct (CPC). In doing so, we examine all sanctions imposed by the AICPA under its CPC from 2008 to 2016 to determine the extent to which a state board's reporting of violations to the AICPA is associated with its full, partial, or non-adoption of the AICPA's CPC. Our findings suggest that widespread full adoption of the AICPA's CPC might not result in enhanced state board participation in reporting violations to the AICPA, as might otherwise be expected. Indeed, we find that state boards that partially adopt the AICPA's CPC report the most violations. We also highlight the variability of state board participation in monitoring the misconduct of accounting professionals and provide suggestions for enhanced monitoring.
\end{abstract}

\section{Introduction}

The American Institute of Certified Public Accountants (AICPA) is the preeminent national professional accounting association in the United States (U.S.) and, by its own pronouncements, maintains and enforces the profession's most widely applicable code of professional conduct (CPC). Jenkins et al. (2018) recently found that the AICPA relies heavily on state boards of accountancy (i.e., licensing bodies) to help monitor the adherence of accountants to its CPC, as state boards reported more than one-third of CPC-related violations that resulted in AICPA sanctions from 2008 to $2013 .{ }^{1}$ Indeed, any failure in this monitoring stands to threaten those who rely on information prepared or certified by accountants. To achieve a uniform set of behavioral standards across the profession, the AICPA encourages state boards to adopt its CPC (AICPA, 2015a). For state boards that adopt, there is an implicit obligation to report CPC violations to the AICPA for centralized aggregation and analysis. Because state boards can choose to fully, partially, or not adopt the AICPA's CPC, it remains an open question to what extent a state board's reporting of violations to the AICPA is associated with its degree of adoption of the AICPA's CPC. Our study seeks 
to answer this question by examining violation reporting levels of U.S. state boards of accountancy to the AICPA. ${ }^{2}$ Based on our findings, we offer commentary on the current role of state boards in the national effort to monitor CPC-related violations, highlight key public policy implications, and offer suggestions for improvement.

Previous studies have examined enforcement of the CPC and its role in the accounting profession. Beyond Jenkins et al. (2018), there is a stream of research that examines the extent to which codes of conduct/ethics protect the public interest or the private interests of the accounting profession (e.g., Loeb, 1972; Parker, 1987, 1994; Schaefer and Welker, 1994; Bédard, 2001; Canning and O’Dwyer, 2001, 2003). Another prominent stream of research documents common problems with accountants' conduct and associated sanctions under the CPC (e.g., Tidrick, 1992; Badawi and Rude, 1995, 1997; Moriarity, 2000; Badawi, 2002; Armitage and Moriarity, 2016; Jenkins et al. 2018). There is also research that examines codes of ethics and self-regulation in the accounting profession (e.g., Loeb, 1984, 1986). However, these streams of research do not consider the logistics of monitoring a national accounting profession as large as the one in the U.S., in which 55 states and territories have independent boards of accountancy that may report violations to the AICPA. In one regard, having state boards spread throughout the country should ensure close monitoring of all accounting professionals. However, state boards may vary in their level of participation in reporting violations for various reasons, such as (a lack of) adoption of the AICPA's CPC, budget constraints, or views on the types of violations that are reportable to the AICPA.

We examine the extent to which a state board's reporting of violations to the AICPA is associated with its degree of adoption of the AICPA's CPC. If a state board willingly chooses to adopt the AICPA's CPC either in whole or in part, there is an implicit obligation to report violations of the CPC to the AICPA. State boards that do not adopt the CPC do not have this implicit obligation and are more likely to remain disengaged from the AICPA's efforts to monitor the accounting profession under a common framework and to centrally aggregate misconduct issues. Still, there is research that suggests adoption (on its own) might not be associated with higher levels of violation reporting. For example, Adam and Rachman-Moore (2004) find that an effective code of conduct implementation requires informal buy-in from constituents.

To determine the extent to which a state board's reporting of violations to the AICPA is associated with its degree of AICPA CPC adoption, we evaluate state boards' reporting of violations from 2008 to 2016 along with their degree of adoption of the AICPA's CPC. In doing so, we collected data from a variety of sources including (1) online resources (both public and privileged resources), (2) the AICPA and National Association of State Boards of Accountancy (NASBA), and (3) through inquiries of the state boards. Descriptive analyses reveal inconsistent and non-uniform monitoring, enforcement, and reporting by state boards under the AICPA's CPC. Further, the number of violations reported by state boards does not appear to be merely an artifact of the number of CPAs in a state or the state population, and there do not appear to be regional differences in the reporting of violations. We also find that state boards that partially adopt the AICPA's CPC report the most violations. States with full adoption appear to be less engaged in helping the AICPA monitor the conduct of accounting professionals, and tend to have smaller operating budgets, particularly when compared to states with partial adoption of the AICPA's CPC. Finally, we conduct a regression analysis to assess the impact of factors that might explain variation in the number of violations reported to the AICPA. Overall our findings suggest that widespread full adoption of the AICPA's CPC by state boards might not result in enhanced participation in reporting violations to the AICPA as might otherwise be expected. That is, we do not find evidence that violation reporting follows naturally from an adoption of the AICPA's CPC. As such, we believe the AICPA should more strongly emphasize to state boards the importance of reporting CPC violations and "buying into" enhanced monitoring of misconduct.

Our study is important for several reasons. First, the AICPA encourages state boards to adopt its CPC, as nationwide adoption would align all CPAs under the same framework for ethical and behavioral standards (AICPA, 2015a). While adoption of the CPC should come with an implicit obligation for state boards to monitor misconduct and report violations to the AICPA, we find inconsistent reporting by state boards both within and across adoption statuses (i.e., none, partial, or full adoption of the $\mathrm{CPC}$ ). This finding is unexpected because violations should be more evenly distributed across time and location. Thus, our findings suggest that state board adoption of the AICPA's CPC, on its own, is not sufficient to achieve more active or uniform state board reporting. Further, the observed inconsistencies in state board reporting contributes to the broader issue that no single party has a comprehensive understanding of the misconduct of accounting professionals across the U.S. We emphasize that regulating CPA behavior is important for the overall social good (i.e., protecting the public interest), and a failure to monitor adherence to the CPC by state boards threatens a wide spectrum of users of accounting information as well as the inner-workings of the accounting profession (including its ability to self-regulate) because misconduct may not be detected or corrected. According to James W. Brackens, Jr., Vice President - Ethics and Practice Quality for the AICPA, consequences to the AICPA and the profession include inconsistent or uneven sanctions against CPAs for the same violation, less effective peer review processes, and inadequate educational materials related to the CPC. Thus, we highlight an important public policy issue in the potential for inconsistent monitoring and enforcement of the AICPA CPC through non-uniform reporting of violations by boards of accountancy. The AICPA can use these findings to inform efforts to encourage state boards to both adopt its CPC and commit to a program of active monitoring and reporting of violations. Finally, we call for more transparency into the effective use of state board operating budgets.

\footnotetext{
2 The AICPA can become aware of violations identified by state boards of accountancy through direct communications from state boards or by reviewing state board publications. For expositional purposes, when we refer to state boards reporting violations to the AICPA, we are collectively referring to situations in which a state board (1) directly communicates violations to the AICPA or (2) indirectly communicates this information through other outlets (e.g., publications) that the AICPA can review. Where appropriate, we make specific reference to the method used.
} 
The remainder of our paper is organized as follows. First, we provide an overview of past research in the area and present our research question. Next, we describe our methodology. The penultimate section presents our findings. We conclude with a discussion of our findings and policy implications.

\section{Background}

\subsection{The AICPA and state boards of accountancy}

The AICPA serves the accounting profession a number of ways, one of which includes providing and maintaining the only national-level CPC for accountants practicing in the U.S. While the AICPA CPC provides a common set of ethical standards applicable to a wide range of professional accounting services, the AICPA faces challenges in implementing and monitoring adherence to its CPC. For example, the initial licensing and continued maintenance (i.e., periodic renewal) of the CPA designation are controlled at the state board of accountancy level and neither requires membership in the AICPA. ${ }^{3}$ Indeed, professional certification only requires CPAs to demonstrate fluency with the code of ethics adopted by the licensing board in the state (s) they wish to maintain certification. ${ }^{4}$ CPAs are therefore not automatically subject to the AICPA's CPC. ${ }^{5}$ To combat this challenge the AICPA encourages state boards to adopt its CPC (in whole or in part) and report related instances of member violations (AICPA, 2015a). As of July 2015, 31 states had partially or fully adopted the AICPA CPC (15 partial; 16 full) (AICPA, 2015b). ${ }^{6}$ In this study, we examine trends in state boards' of accountancy reporting of CPC-related violations to the AICPA, along with other state/state board attributes, and seek to answer to what extent a state boards' degree of AICPA CPC adoption is associated with different levels of participation in the national effort to monitor the misconduct of accounting professionals under a common set of ethical standards.

Violation reporting is used by the AICPA for a number of purposes such as developing educational programs and outreach activities, determining appropriate disciplinary sanctions for CPC violations, and assisting professionals who conduct peer reviews in planning their reviews. This reporting affords the AICPA access to information about the breadth and nature of CPC violations across the profession that is necessary to accomplish each of these purposes and to enable the AICPA to maintain, and revise as necessary, a code of conduct that embodies "the profession's recognition of its responsibilities to the public, to clients [emphasis in the original], and to colleagues" (AICPA, 2016, 5). The cost of failures in such reporting is borne by the public (e.g., creditors, governments, employers, investors, and the business and financial communities), clients, and members of the profession itself.

There are two significant consequences of inadequate violation reporting by state boards according to James W. Brackens, Jr., the AICPA's Vice President - Ethics and Practice Quality. First, the AICPA cannot take effective remedial action against a CPA if it is unaware of the individual's misconduct and the circumstances surrounding it. While state boards may take their own action against a CPA, individuals in one jurisdiction may receive one type of sanction (e.g., additional continuing professional education requirements) while an individual in another jurisdiction may face a different sanction (e.g., a civil penalty or temporary suspension of the CPA license). AICPA sanctions are not limited by state or federal statutes and can be modified in a manner that is believed to be most effective at remediating the CPA's misconduct. In exercising this flexibility, the AICPA believes it is able to provide strong public protections nationwide. Second, violation reporting is considered a significant factor during the risk assessment process in peer reviews. For example, if violation reporting reveals that a CPA has been sanctioned by a state board for failing to comply with professional standards on an audit engagement (e.g., failing to exercise due care or not complying with annual continuing education requirements), then peer reviewers can adjust their approach to examining other engagements that fall within the purview of their review. Thus, deficiencies in professional services may go undetected if peer reviewers are unaware of CPC violations or related problems on past engagements.

Fifty states and five territories in the U.S. maintain a board of accountancy (or equivalent), and as such, are relevant in helping the AICPA monitor the accounting profession under its CPC (NASBA, 2018a). ${ }^{7}$ In this study, however, we focus on boards of the 50 U.S. states due to the broader availability of supplemental data and given this focus provides over $98 \%$ coverage of licensed CPAs in the U.S. (per data provided by NASBA as of 2016). There are two general ways the AICPA is made aware of violations identified by these state boards: (1) through direct communications from the state boards or (2) indirectly through other outlets (e.g., publications) made available by the state boards that identify instances of state boards/entities sanctioning members for misconduct. In many cases, state boards will take corrective action against a member for misconduct, and upon learning of this action the AICPA will automatically impose a similar sanction (Armitage and Moriarity, 2016; Jenkins et al. 2018). Participation from state boards is therefore critical for the AICPA to compile a comprehensive list of CPC violations

\footnotetext{
3 Still, the AICPA reports a current membership of 418,000 (AICPA, 2018a).

${ }^{4}$ Many state boards of accountancy require CPA candidates to complete a course on ethics but there is variation in what those courses cover and associated requirements for ethics-specific CPE hours. While such courses may cover state-specific rules and professional standards, content may also cover elements of the AICPA CPC. Further, many states also require continuing professional education (CPE) training in ethics or professional standards, and failure to comply can result in the suspension or revocation of CPA licensure.

${ }^{5}$ However, the Uniform Accountancy Act promotes the AICPA CPC as the model against which CPAs' ethical conduct should be measured in the U.S. (AICPA, 2014).

${ }^{6}$ We use the CPC adoption status of states as of July 2015, the earliest point at which the AICPA began tracking adoption by jurisdictions. However, data that is more recent is available from the AICPA. See: http://www.aicpa.org/Advocacy/State/Pages/AdoptingtheAICPACodeofProfessionalConduct.aspx.

7 These same 55 states and territories also maintain independent CPA societies (AICPA, 2018b).
} 
and to impose appropriate sanctions. However, it remains unknown the extent to which state boards' (degree of) adoption of the AICPA's CPC is associated with different levels of participation in reporting violations to the AICPA.

While prior studies have not analyzed the impact of CPC adoption on violation reporting, there are two primary streams of research that have examined enforcement of the CPC and its role in the accounting profession.

\subsection{Research in accounting on codes of professional conduct}

Several studies examine whether a CPC is used to protect the private interest of the accounting profession or the broader public interest. Loeb (1972) examined CPC violations and related sanctions within one U.S. state from 1905 to 1969 and found more severe sanctions were imposed for violations of public rather than private interest matters. Parker (1994) developed a five-factor private interest model and demonstrated that the professional accounting ethics code in Australia served to protect the profession's private interests. Canning and O'Dwyer (2001) investigated the disciplinary procedures used by the Institute of Chartered Accountants in Ireland (ICAI) and found such procedures protect the private interests of the accounting profession. Bédard (2001) found that public interest violations are deemed more serious and carry heavier sanctions for accounting professionals during the open trial stage of disciplinary hearings (in Québec, Canada). Finally, Jenkins et al. (2018) show that sanctions were imposed under the AICPA CPC from 2008 to 2013 primarily in defense of the public interest.

Other research examines instances of AICPA CPC violations and resulting sanctions. Moriarity (2000) studied AICPA sanctions from 1980 to 1998 and found that members were most commonly sanctioned under the CPC as a result of criminal convictions. Tidrick (1992) reported similar findings for sanctions imposed from 1980 to 1990. Using a more limited sample period from 1994 to 1995, Badawi and Rude $(1995,1997)$ found that sanctions were most commonly the result of substandard professional work. Most recently, Jenkins et al. (2018) found sanctions from 2008 to 2013 were most commonly applied for acts discreditable to the accounting profession. In terms of specific types of sanctions imposed, Moriarity (2000) found suspensions were most often imposed for issues of substandard professional service. Results from Tidrick (1992), Badawi and Rude $(1995,1997)$ and Jenkins et al. (2018) show expulsions/terminations to be the most common form of sanction for violations of the AICPA's CPC. As such, this area of research identifies prevalent issues with misconduct and how the profession responds with disciplinary sanctions. ${ }^{8}$

The streams of research just described are important because they help the profession understand the most common types of CPC violations, how violations are sanctioned, and how accounting CPCs are used (i.e., serving public vs. private interests). However, these studies do not examine the level of participation from licensing boards (i.e., state boards of accountancy) in providing continuous monitoring of the conduct of accounting professionals, nor whether widespread adoption of a common CPC assists in this endeavor. Indeed, Jenkins et al. (2018) found that 35.6 percent (210/590) of AICPA sanctions imposed from 2008 to 2013 were originally reported by state boards of accountancy, and remaining sanctions were reported by "entities" such as the AICPA, Securities and Exchange Commission (SEC), Internal Revenue Service (IRS), and Public Company Accounting Oversight Board (PCAOB).$^{9}$ Therefore, state boards play a major role in the AICPA's effort to identify and report violations of accounting professionals across the U.S. Considering there are 50 state boards of accountancy in the U.S. that vary in their degree of adoption of the AICPA's CPC, it is unlikely that each board participates to the same extent in monitoring misconduct, enforcing sanctions, and ultimately reporting violations to the AICPA.

\subsection{CPC adoption, monitoring, and enforcement}

The AICPA encourages state boards to adopt its CPC because nationwide adoption would align all CPAs under the same framework for ethical and behavioral standards (AICPA, 2015a). Nonetheless, because the AICPA is a voluntary membership organization, state boards can choose to fully, partially, or not adopt the AICPA's CPC as their own. Whichever option a state board chooses, ex ante the number of CPC violations that occur should be evenly distributed across time periods and states. However, if a state board fully or partially adopts the AICPA's CPC, there is an implicit obligation for that board to report violations of the CPC to the AICPA. On the other hand, state boards that do not adopt the CPC do not have this implicit obligation and are likely less engaged with the AICPA's efforts to monitor accounting professionals' ethical conduct and to centrally aggregate misconduct issues. However, there is research that suggests adoption (on its own) might not be associated with higher levels of violation reporting, and that violation reporting might also relate to how state boards choose to implement monitoring and enforcement (i.e., oversight) activities.

Falk and Kosfeld (2006) discuss the hidden cost of control in a principal-agent model and show that as more control is applied by a principal over an agent, the agent perceives that action as a sign of distrust and limitation of their choice

\footnotetext{
${ }^{8}$ We specify here "how the profession responds" as the AICPA commonly imposes sanctions commensurate with those imposed by the party that first identified the misconduct, such as the Internal Revenue Service (IRS), Securities and Exchange Commission (SEC), or state boards of accountancy. We focus this study on state boards of accountancy as Jenkins et al. (2018) found that state boards report more violations that lead to AICPA sanctions than any other party.

${ }^{9}$ We make several references that indicate a state board or entity "reported violations" to the AICPA. Here, we are broadly referring to the party who originally identified and communicated/made available through other outlets (e.g., publications) the violation that lead to disciplinary sanctions. For example, when we say the AICPA reported violations, this does not imply the AICPA reported to itself, but instead the AICPA was the first party to record the member violation that lead to disciplinary sanctions under the CPC.
} 
autonomy. In our study's context, state boards that feel under the control of the AICPA might actually reduce their monitoring activities. Similarly, Adam and Rachman-Moore (2004) study the implementation of codes of conduct and find that formal methods of adoption are necessary but not sufficient; rather, an effective implementation requires both formal and informal buy-in. This suggests that full adoption of the AICPA's CPC (i.e., formal adoption) alone may be less effective than when paired with an informal buy-in such as when state boards develop and maintain their own codes of conduct alongside the AICPA's CPC. Together, these findings raise some doubt as to whether a state board's fuller adoption of the AICPA's CPC is associated with higher levels of violation reporting. To summarize, various factors likely influence a state board's reporting of violations to the AICPA. In this study, we focus on one of the more observable relevant factors, that being the state boards' (degree of) adoption of the AICPA's CPC as it relates to state boards reporting violations of the CPC. In doing so, we seek to answer the following research question:

RQ: To what extent is a state board's reporting of violations to the AICPA associated with its degree of adoption of the AICPA's CPC?

Next, we describe the data collected to examine the association between participation in reporting violations to the AICPA and state board (degree of) AICPA CPC adoption.

\section{Data collection}

NASBA recognizes 55 boards of accountancy in the U.S., which include the boards of the 50 U.S. states, Washington, D.C., Puerto Rico, the U.S. Virgin Islands, Guam, and the Commonwealth of the Northern Mariana Islands (NASBA, 2018a). As previously stated, we focus on boards in the 50 U.S. states due to the broader availability of supplemental data and given this focus provides over $98 \%$ coverage of the active CPAs in the U.S. ${ }^{10,11}$ We collected data through three sources: (1) online resources (including both public and privileged resources), (2) the AICPA and NASBA, and (3) our inquiries of the state boards of accountancy. Next, we describe the data collected through each of these sources.

\subsection{Data from online resources}

The data we collected from online resources cover a variety of areas. To begin, we collected all available state board of accountancy (annual) operating budgets for 2008 to 2016. In doing so, we obtained budgets for some/all years in our examined time period for 39 of the 50 state boards, and ultimately collected 291 state board/year observations. ${ }^{12}$ Budgets for other boards were either unavailable or included in as components of larger budgets with other administrative bodies (i.e., umbrella agencies) such that separate board of accountancy operating budgets could not be separately identified. We also collected statelevel annualized CPA licensing fees, CPA continuing professional education (CPE) requirements, information on whether state boards use the AICPA's ethics exam or implement their own ethics exam (or a combination thereof), state board license renewal periods, CPE reporting periods, and other state requirements for licensure (e.g., experience requirements). Further, in recognizing the varying economic conditions during our analysis period, we also obtained state-level gross domestic product (GDP) data for 2008 to $2016 .^{13}$ This data is particularly important because our study's period includes three years of the Great Recession (i.e., 2008 to 2010). Finally, we obtained the number of public company headquarters, by state and year, from Compustat.

\subsection{Data from the AICPA and NASBA}

We obtained violations data from the AICPA quarterly compilations of all disciplinary sanctions imposed on its members under the CPC for the nine-year period beginning January 2008 and ending December 2016. In assembling these quarterly compilations, the AICPA lists member violations as reported by state boards and other entities, such as the AICPA, SEC, IRS, and PCAOB. Further, the AICPA may also become aware of member violations by review of state board publications, enforcement releases (from entities), and news articles. Thus, the AICPA learns of member violations through (1) state board/entity direct communications and (2) other outlets (e.g., publications) made available that identify instances of state boards/entities sanctioning members for misconduct. ${ }^{14}$ We refer to both the direct communications, and the making of this information available through other outlets, as the "reporting" of member violations. Our data consist of the 358 sanctions the AICPA

\footnotetext{
${ }^{10}$ We also chose to focus on the 50 U.S. states as other research has focused on specific nuances found in U.S. territories such as Puerto Rico (e.g., Cardona et al. 2019).

11 We rely on the AICPA's accumulation of state-level violation and sanction information because this same information is generally not publicly available from the states. As will be further discussed in Section 3.3, we contacted the state boards individually to better understand which states report violations to the AICPA and the frequency of this reporting.

12 State boards with no operating budgets for any years in our data include Delaware, Hawaii, Indiana, Maine, Massachusetts, Michigan, New Jersey, New York, Pennsylvania, Utah, and Wisconsin.

13 This data is publicly available from the Bureau of Economic Analysis. See: https://www.bea.gov/regional/downloadzip.cfm

14 Prior to November 2009, the AICPA reported disciplinary sanctions in its newsletter, The CPA Letter. Since this time, disciplinary sanctions for AICPA members have appeared on the Disciplinary Actions section of the AICPA website, and summary listings periodically appear in the Wall Street Journal. The use of online postings complicates the process of obtaining and summarizing past member sanctions, as the data are removed after a set period of time. We therefore worked with the AICPA's Professional Ethics Division and obtained copies of the original quarterly compilations. In doing so, the AICPA removed member names from each entry, although names appear in the original online postings.
} 
imposed upon members under its CPC from 2008 to 2016 based on conduct violations reported by 35 state boards (i.e., 15 state boards did not report any violations during this time period). ${ }^{15}$ These 358 records represent the complete population of sanctions known by the AICPA during the study period. ${ }^{16}$ Thus, related analyses are not performed on a sample basis.

The AICPA also provided a listing of state boards of accountancy that had fully, partially, or not adopted the AICPA CPC as their own as of July 2015. As shown in Table 1, 16 state boards had fully adopted, 15 had partially-adopted and 19 had not adopted the AICPA CPC as of July 2015 (AICPA, 2015b).

Finally, to gauge the relative CPA population by state, we obtained the number of CPA licensees per state from NASBA (as of 2016). ${ }^{17}$

\subsection{Data from inquiries of the state boards of accountancy}

To gain a more complete perspective on state board participation in CPC monitoring, we independently contacted the 50 U.S. state boards of accountancy and inquired as to their practices/policies on directly communicating CPC violations to the AICPA. We focused our efforts on the boards of accountancy instead of the CPA societies because practitioner licenses are board-controlled, membership in CPA societies is voluntary, and there were no violations in our dataset reported to the AICPA by any state CPA society. In identifying an appropriate representative (e.g., executive director) for each board, we used contact information published online by NASBA. ${ }^{18}$ Each representative was originally contacted by phone, and additional follow-up questions were managed through email communication. We asked each representative three questions related to their state board's participation in the AICPA's efforts to monitor the accounting profession at the national level:

1. Does the state board periodically directly communicate CPC violations to the AICPA?

2. How often are CPC violations directly communicated to the AICPA?

3. Which CPC violations are directly communicated to the AICPA?

We obtained responses to our inquiries from 48 of the 50 state boards, but failed to receive a response from Illinois and New Jersey.

Table 2 summarizes results for those boards that directly communicate violations to the AICPA. ${ }^{19}$ We find the 17 boards that claim to directly communicate violations do so with varying frequencies, ranging from in real-time as violations occur to once every three years. The severity of violations directly communicated also varies, ranging from all known violations to only those considered by the state board to be "serious." ${ }^{20}$ Our findings indicate there is no consistent reporting mechanism in place at the state board of accountancy level for the AICPA to be made aware of all instances of member CPC violations. Consequently, the AICPA's ability to monitor accounting professionals on a national level is limited. Further, in considering the adoption status of the 17 state boards that directly communicate violations to the AICPA, we note that 41.2 percent (7/17) have not adopted the AICPA CPC either in whole or in part. Thus, not adopting the AICPA's CPC does not preclude a state board from participating with the AICPA in monitoring the accounting profession at the national level.

\section{Analyses}

\subsection{Descriptive analyses}

\subsubsection{State board reporting of violations}

Our inquiries with state boards revealed which ones participated in directly communicating CPC violations to the AICPA and to what extent. While this information was gathered at a point-in-time (spring 2013), it was important to see if our data on violations reporting from the AICPA matched the feedback from the state boards. We use Fig. 1 to broadly examine the number of unique state boards that reported violations to the AICPA (that resulted in disciplinary sanctions) from 2008 to

\footnotetext{
$\overline{15}$ We exclude 146 violations identified as part of a New Jersey audit of practitioner CPE compliance performed during 2013. Each of these 146 instances relates to CPE violations, and are excluded from our study because they represent the specific enforcement actions of one state.

${ }^{16}$ Krom (2019) reports 769 disciplinary actions against CPAs across four states (California, Texas, Illinois, and New York) from 2008 to 2014, whereas we report 358 disciplinary actions across the United States from 2008 to 2016. The difference in these totals is due to the population of interest and data set/sources. Specifically, the population in our study is the number of sanctions imposed by the AICPA under its CPC, whereas Krom's (2019) population is the number of disciplinary actions published/publicized by four state boards. Further contributing to this difference: (1) the AICPA might not act on a state board's reported disciplinary action because it does not map to the AICPA's CPC, (2) Krom $(2019,574)$ reports "ricochet" sanctions that appear multiple times in the dataset as a single CPA being disciplined by multiple state boards for the same offense, and (3) the burdensome data collection process as documented in this study and Krom (2019) makes it possible that the AICPA might not have located all the state board disciplinary actions during this time period.

17 This data is not publicly available and was directly requested from NASBA to align with the final year evaluated in our data set.

${ }_{18}$ Access to state boards of accountancy via the NASBA website is available at: http://nasba.org/stateboards/.

19 As previously described, the AICPA can become aware of violations identified by state boards of accountancy through direct communications from state boards or by reviewing state board publications. With our dataset, it is not possible to determine which of these two methods was used to identify each of the 358 violations made available by state boards from 2008 to 2016. However, our inquiries with the AICPA indicate that there are only four state boards that directly communicate violations on a consistent basis: Kansas, Michigan, Nevada, and Wisconsin. Our inquiries with state boards help reveal the reporting practices followed at the individual state boards of accountancy level.

${ }^{20}$ Colorado did not indicate the types of violations that would be reported to the AICPA due to not having a violation tracking mechanism in place at the time of inquiry.
} 
Table 1

State board adoption status of the AICPA CPC as of July 2015.

\begin{tabular}{lll}
\hline Not Adopted & Full Adoption & Partial Adoption \\
\hline Alabama & Delaware & Alaska \\
Arizona & Idaho & Colorado \\
Arkansas & Indiana & Kansas \\
California & Maine & Nevada \\
Connecticut & Michigan & New Jersey \\
Florida & Minnesota & North Carolina \\
Georgia & Missouri & Ohio \\
Hawaii & New Hampshire & Oregon \\
Illinois & New Mexico & Pennsylvania \\
Iowa & North Dakota & Tennessee \\
Kentucky & Oklahoma & Texas \\
Louisiana & Rhode Island & Vermont \\
Maryland & South Carolina & Washington \\
Massachusetts & South Dakota & Wisconsin \\
Mississippi & Utah & Wyoming \\
Montana & Virginia & \\
Nebraska & & \\
New York & & \\
West Virginia & & \\
\hline
\end{tabular}

This table presents the status of state boards adopting the AICPA CPC based on information provided by the AICPA as of July 2015. Boards in the "Not Adopted" category have not adopted the CPC, while those in "Full Adoption" have adopted the CPC in its entirety. Boards with "Partial Adoption" have either adopted (1) sections of the CPC or (2) the entire CPC with exceptions.

2016 along with the number of violations reported by those boards in each year. As shown, the number of state boards reporting violations ranges from the lowest level of seven in 2008 to the highest level of 21 in 2013 , while the number of violations reported in a single year ranges from 14 in 2010 to 79 in 2014. The variation of boards' reporting and number of violations reported suggest the potential for inconsistent and non-uniform monitoring, enforcement, and reporting under the AICPA's CPC.

Next, we compiled Table 3 to examine which state boards participated most in reporting violations from 2008 to 2016. Table 3 details the state boards that reported violations that resulted in AICPA sanctions under the CPC, in descending order. As shown, North Carolina (57) reported the most violations during this period, followed by Arizona (36) and Texas (30). Further, 15 state boards did not report any violations from 2008 to 2016. We also incorporated state population and number of CPA licenses data to determine if the number of violations reported was an artifact of state size. When the number of violations reported is normalized by the number of active CPA licenses per state, the state with the most violations reported per CPA is Kansas (5.504) followed by Arizona (3.595) and Alabama (3.076) (as described in Table 3, these figures are reported per 1000 CPAs for more meaningful comparisons). ${ }^{21}$ Analyses in Table 3 suggest that violation reporting by state boards is likely impacted by factors beyond the state's population and size of its accounting profession.

Given the findings from Table 3, we next compiled a geographic representation of the number of violations reported to identify potential regional differences. Fig. 2 is a heat map of the U.S. population per the 2010 U.S. Census overlaid by the number of violations reported by each state board for the period of 2008 to 2016 (note that Alaska and Hawaii did not report any violations during this period). Our visual inspection does not reveal any apparent regional differences in the reporting of violations.

\subsubsection{State boards' adoption of the AICPA CPC}

As previously described, the primary question in our study is to what extent a state board's reporting of violations to the AICPA is associated with the degree of adoption of the AICPA's CPC. As shown in Table 1, states can fully (16), partially (15), or not adopt (19) the AICPA's CPC. If a state board fully or partially adopts the AICPA's CPC, there is an implicit obligation for that board to report known violations of the CPC to the AICPA. State boards that do not adopt do not have this obligation and are likely to be less engaged with the AICPA's efforts to monitor accounting professionals' ethical conduct and to centrally aggregate misconduct issues. We use a bubble chart in Fig. 3 to examine this relationship between the number of violations reported (bubble size) and the degree of AICPA CPC adoption by a state (bubble shade). It is apparent that states reporting the most violations have not fully adopted the AICPA's CPC. ${ }^{22}$ Additional analyses reveal that the 16 state boards with full adoption

\footnotetext{
${ }^{21}$ Although AICPA membership data is not publicly available by state, we also include state population data from the 2010 U.S. Census (United States Census Bureau, 2010), as discussions with the AICPA indicate that state population is a valid proxy for relative AICPA membership by state. A separate ranking per capita by state population is not provided given the correlation between the number of active CPA licenses and state population $(r=0.935, p<0.001$, twotailed; $\rho=0.951, \mathrm{p}<0.001$, two-tailed).

${ }^{22}$ Specifically, North Carolina reported 57 violations with partial adoption of the AICPA's CPC, Arizona reported 36 violations with no adoption, Texas reported 30 violations with partial adoption, California reported 25 violations with no adoption, and Kansas reported 22 violations with partial adoption.
} 
State boards purporting to directly communicate code of professional conduct (CPC) violations to the AICPA.

\begin{tabular}{|c|c|c|c|c|}
\hline & \multicolumn{3}{|l|}{ Results of Independent Inquiries } & \multirow[b]{2}{*}{$\begin{array}{l}\text { Did State Board Report Violations } \\
\text { (i.e., Directly Communicate or Make } \\
\text { Available) to the AICPA from } 2008 \\
\text { to } 2016 \text { ? }\end{array}$} \\
\hline & $\begin{array}{l}\text { Does the board periodically directly } \\
\text { communicate CPC violations to the } \\
\text { AICPA? }\end{array}$ & $\begin{array}{l}\text { Frequency with which CPC } \\
\text { violations are directly } \\
\text { communicated to the AICPA }\end{array}$ & $\begin{array}{l}\text { Which CPC violations } \\
\text { are directly } \\
\text { communicated to the } \\
\text { AICPA? }\end{array}$ & \\
\hline Alabama & Yes & As Occur & All & Yes \\
\hline Arizona & Yes & Monthly & All & Yes \\
\hline California & Yes & Bi-Monthly & All & Yes \\
\hline Colorado & Yes & As Occur & Unknown & Yes \\
\hline Idaho & Yes & Quarterly & All & Yes \\
\hline Kansas & Yes & As Occur & All & Yes \\
\hline Kentucky & Yes & Every Other Year & Comm $>$ NoEdu & Yes \\
\hline Louisiana & Yes & As Occur & Comm.Disc & No \\
\hline Nebraska & Yes & Every Three Years & Comm.Serious & No \\
\hline $\begin{array}{l}\text { North } \\
\quad \text { Carolina }\end{array}$ & Yes & As Occur & Comm.Rev/Sus & Yes \\
\hline $\begin{array}{l}\text { South } \\
\quad \text { Carolina }\end{array}$ & Yes & As Occur & Comm $>$ Admin & Yes \\
\hline Tennessee & Yes & Quarterly & Comm $>$ Admin & Yes \\
\hline Vermont & Yes & As Occur & All & No \\
\hline Washington & Yes & Quarterly & Comm $>$ Admin & Yes \\
\hline Wyoming & Yes & As Occur & Comm.Suspen & Yes \\
\hline Nevada & Yes.1 & As Occur & Comm $>$ Admin & Yes \\
\hline Montana & Yes.2 & As Occur & Comm.Disc & No \\
\hline
\end{tabular}

This table presents the results of our outreach to the state boards of accountancy (or equivalent body for states without a "state board of accountancy"). Only boards that indicated some level of directly communicating CPC violations to the AICPA are included in this table (i.e., those not listed indicated that they do not directly communicate CPC violations to the AICPA). For those boards directly communicating violations, we also inquired as to the frequency with which CPC violations are directly communicated to the AICPA and which CPC violations are communicated. Inquiries were performed primarily during March and April of 2013. Note that after repeated attempts, we failed to receive responses to our inquiries from Illinois and New Jersey; as such, the results presented in this table do not make any conclusions as to the communications practices of these two state boards.

Yes.1: Yes, if the state board is aware that the violation was committed by a member of the AICPA.

Yes.2: Only in certain situations.

As Occur: Violations are directly communicated by the state board to the AICPA as they occur (i.e., not on a defined reporting frequency).

Monthly: Violations are directly communicated by the state board on a monthly basis.

Bi-Monthly: Violations are directly communicated by the state board after bi-monthly board meetings.

Quarterly: Violations are directly communicated by the state board on a quarterly basis.

Every Other Year: Violations are directly communicated by the state board every-other year.

Every Three Years: Violations are directly communicated by the state board every three years.

All: All disciplinary actions are directly communicated to the AICPA by the state board.

Comm.Rev/Sus: All disciplinary actions that result in the revocation or suspension of a certificate are directly communicated to the AICPA by the state board. Comm > Admin: All disciplinary actions except administrative actions are directly communicated to the AICPA by the state board.

Comm > NoEdu: All disciplinary actions except continuing education violations are directly communicated to the AICPA by the state board.

Comm.Serious: Only those violations deemed "serious" by the state board are directly communicated to the AICPA.

Comm.Suspen: Only those violations that result in suspensions are directly communicated to the AICPA.

Comm.Disc: The state board maintains discretion as to which violations it chooses to directly communicate to the AICPA.

Unknown: The respondent could not provide feedback considering the lack of a tracking mechanism in place.

collectively reported 50 violations from 2008 to 2016, meaning that 32 percent (16/50) of the states reported only 14 percent (50/358) of the total violations. This stands in contrast to 30 percent $(15 / 50)$ of state boards with partial adoption that reported 50.3 percent (180/358) of the violations, and the 38 percent (19/50) of state boards that have not adopted and still report 35.7 percent (128/358) of the violations. These findings suggest that a full adoption of the AICPA's CPC is not associated with higher levels of violation reporting.

We compiled Table 4 to more closely examine our data when aggregated by the state boards' degree of AICPA CPC adoption. As shown, the extent of violations reported by states with full adoption appears to lag that of states with partial or no adoption across most categories. Specifically, states with full adoption reported the fewest violations both in total (Full $=50$, Partial $=180$, Not $=128$ ) and when averaged by the number of states in that adoption group (Full $=3.125$, Partial $=12.000$, No Adoption $=6.737) .^{23}$ Given our inquiries with the state boards, states with full adoption also directly communicate the least often, and the fewest types of violations, to the AICPA. ${ }^{24}$ Based on these results, it appears that state boards that have fully adopted the AICPA's CPC are less engaged in helping the AICPA monitor the conduct of accounting professionals than states that have partially or not adopted the AICPA CPC.

\footnotetext{
${ }^{23}$ This pattern also persists when the number of violations is normalized by the number of active CPA licenses in a state (Full $=0.409$, Partial $=0.829$, No Adoption $=0.462)$ (note - results are per 1,000 active CPAs).

${ }^{24}$ We also find that CPAs who are licensed by state boards that have fully adopted the AICPA's CPC report CPE least frequently (Full $=2.500$ years, Partial $=$ 2.286 years, No Adoption $=1.947$ years $)$ and pay the lowest average annualized fees for licensure $($ Full $=\$ 99.51$, Partial $=\$ 123.89$, No Adoption $=\$ 135.42$ )
} 


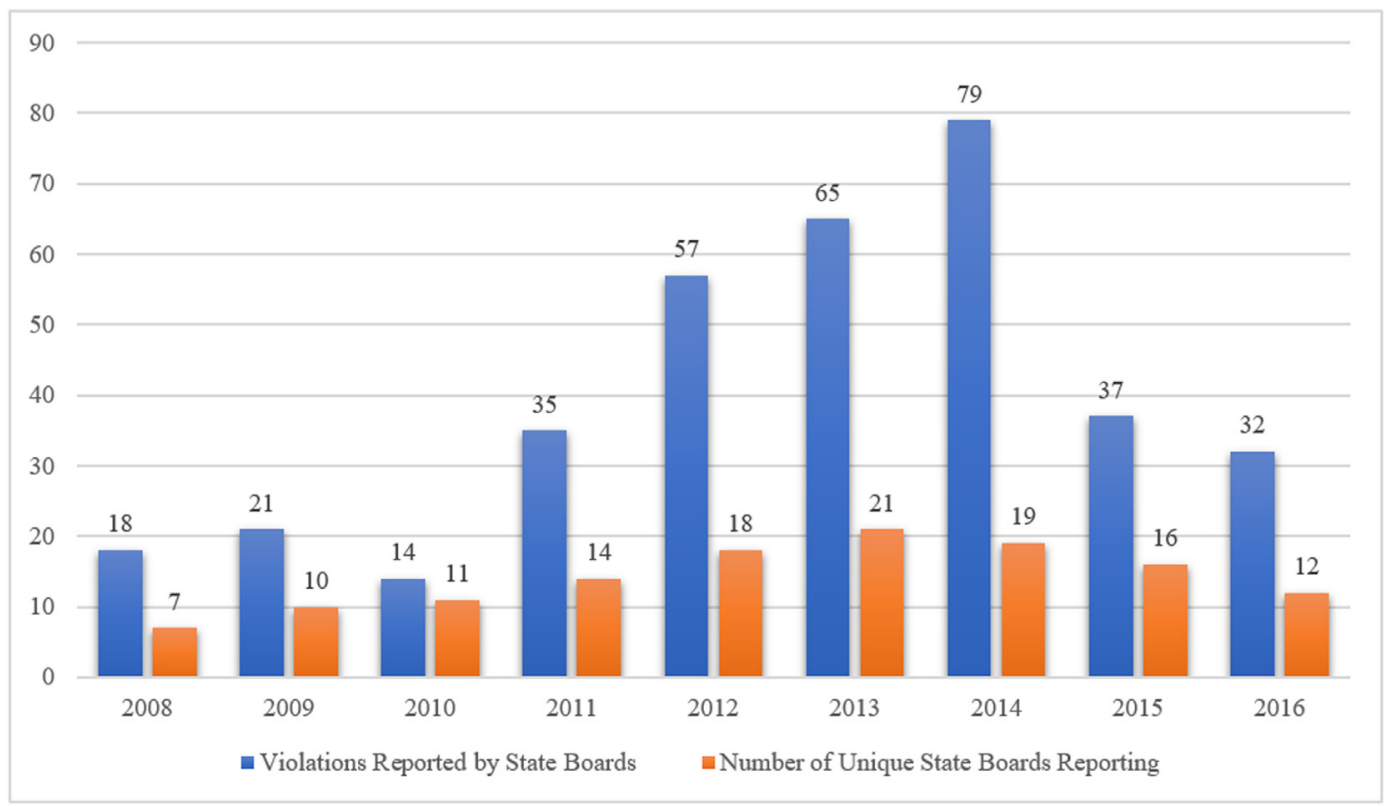

Fig. 1. Number of violations reported by state boards and number of unique state boards reporting violations per year.

\subsubsection{State boards' adoption status, violations reporting, and financial constraints}

As an extension of the previous analysis, we compiled Fig. 4 to visualize the relationships between CPC adoption status, violation reporting, and financial constraints. As shown in Fig. 4, we again aggregated state boards by AICPA CPC adoption status, and then within each adoption status sorted the boards by the number of violations reported from 2008 to 2016 . We then added three columns showing the average state board operating budget from 2008 to 2016 (for the 39 states that we obtained some/all of these budgets), the average operating budget per active CPA license, and the annualized fee for CPA licensure. ${ }^{25}$ Of the 39 states presented, California, Texas, and Washington have the highest average annual operating budgets, while Wyoming, Arkansas, and Alaska have the highest average annual operating budget per active CPA license. States with full adoption have noticeably smaller operating budgets than states that have either partially or not adopted the AICPA CPC, and this appears to remain the case when the operating budget is normalized by the number of active CPA licenses in a state. Correlation analyses confirm this observation, as we note a significant negative correlation between operating budget and degree of AICPA CPC adoption ( $r=-0.179, p<0.001$, two-tailed; $\rho=-0.175, p<0.001$, two-tailed). Finally, annual licensure fees appear to be higher, on average, for states with partial adoption. Based on these observations, states with full adoption have smaller operating budgets, which is consistent with the proposition that fully adopting an established CPC, such as the AICPA CPC, may be a cost-effective strategy for state boards with lower operating budgets (cf. Clements et al. 2009).

Our descriptive analyses reveal several important observations. First, there appears to be inconsistent and non-uniform monitoring, enforcement, and reporting by state boards of accountancy under the AICPA's CPC (Fig. 1). The number of violations reported by state boards does not appear to be merely an artifact of the number of CPAs in a state or the state population (Table 3). There also does not appear to be regional differences in the reporting of violations (Fig. 2). State boards that partially adopt the AICPA's CPC report the most violations (Figs. 3 and 4), while states with full adoption appear to have smaller operating budgets (Fig. 4). Finally, states with full adoption appear to be less engaged in helping the AICPA monitor the conduct of accounting professionals than states that have partially or not adopted the AICPA CPC (Table 4).

\subsection{Correlation analyses}

While the descriptive analyses in the previous section consider targeted relationships among our variables, we provide a complete correlation matrix in Table 5 (all variables are defined in Appendix A). Beyond the correlations already described, we note significant positive correlations between the number of CPA licenses per state (ACTIVE_CPA_LIC) and (1) the 2010 U. S. Population by state $\left(2010 \_P O P\right)(\mathrm{r}=0.935, \mathrm{p}<0.001$, two-tailed; $\rho=0.951, \mathrm{p}<0.001$, two-tailed $)$, and (2) the number of public company headquarters in each state (PUBLIC_HQ) $(\mathrm{r}=0.876, \mathrm{p}<0.001$, two-tailed; $\rho=0.930, \mathrm{p}<0.001$, two-tailed). Not surprisingly, 2010_POP and PUBLIC_HQ are also highly correlated $(\mathrm{r}=0.896, \mathrm{p}<0.001$, two-tailed; $\rho=0.878, \mathrm{p}<0.001$, two-tailed). Furthermore, we find a significant positive correlation between which violations state boards directly communicate to the AICPA $\left(\right.$ WHICH_VIOS) and the frequency with which violations are directly communicated $\left(R P T \_F R E Q\right)(\mathrm{r}=0.799$,

\footnotetext{
${ }^{25}$ We could not identify operating budgets for any year from 2008 to 2016 for the following states, and they have therefore been removed from this analysis: Delaware, Hawaii, Indiana, Maine, Massachusetts, Michigan, New Jersey, New York, Pennsylvania, Utah, and Wisconsin.
} 
Analysis of Violations Reported by State Boards for the period 2008 to 2016.

\begin{tabular}{|c|c|c|c|c|c|c|c|c|}
\hline & \multicolumn{2}{|c|}{$\begin{array}{l}\text { State Board } \\
\text { Reporting } \\
\text { Violation } \\
\end{array}$} & \multicolumn{2}{|c|}{$\begin{array}{l}\text { Active CPA Licensees } \\
\text { in } 2016 \text { (per } \\
\text { NASBA) }^{1} \\
\end{array}$} & \multicolumn{2}{|c|}{$\begin{array}{l}2010 \text { Population (per U. } \\
\text { S. Census Bureau) }\end{array}$} & \multirow[t]{2}{*}{$\begin{array}{l}\text { Violations by Reporting } \\
\text { Jurisdiction per } 1000 \\
\text { Licensees }^{2}\end{array}$} & \multirow[t]{2}{*}{ Rank } \\
\hline & Count & $\%$ & Count & $\%$ & Population & $\%$ & & \\
\hline North Carolina & 57 & $15.9 \%$ & 20,794 & $3.5 \%$ & $9,535,483$ & $3.1 \%$ & 2.741 & 4 \\
\hline Arizona & 36 & $10.1 \%$ & 10,014 & $1.7 \%$ & $6,392,017$ & $2.1 \%$ & 3.595 & 2 \\
\hline Texas & 30 & $8.4 \%$ & 57,947 & $9.7 \%$ & $25,145,561$ & $8.2 \%$ & 0.518 & 15 \\
\hline California & 25 & $7.0 \%$ & 55,330 & $9.2 \%$ & $37,253,956$ & $12.1 \%$ & 0.452 & 18 \\
\hline Kansas & 22 & $6.1 \%$ & 3997 & $0.7 \%$ & $2,853,118$ & $0.9 \%$ & 5.504 & 1 \\
\hline Alabama & 21 & $5.9 \%$ & 6826 & $1.1 \%$ & $4,779,736$ & $1.6 \%$ & 3.076 & 3 \\
\hline Tennessee & 17 & $4.7 \%$ & 10,682 & $1.8 \%$ & $6,346,105$ & $2.1 \%$ & 1.591 & 8 \\
\hline New York & 14 & $3.9 \%$ & 55,549 & $9.3 \%$ & $19,378,102$ & $6.3 \%$ & 0.252 & 28 \\
\hline Missouri & 12 & $3.4 \%$ & 11,370 & $1.9 \%$ & $5,988,927$ & $1.9 \%$ & 1.055 & 9 \\
\hline Oregon & 12 & $3.4 \%$ & 7018 & $1.2 \%$ & $3,831,074$ & $1.2 \%$ & 1.710 & 7 \\
\hline Illinois & 11 & $3.1 \%$ & 20,585 & $3.4 \%$ & $12,830,632$ & $4.2 \%$ & 0.534 & 13 \\
\hline Washington & 11 & $3.1 \%$ & 18,238 & $3.0 \%$ & $6,724,540$ & $2.2 \%$ & 0.603 & 12 \\
\hline Florida & 10 & $2.8 \%$ & 31,179 & $5.2 \%$ & $18,801,310$ & $6.1 \%$ & 0.321 & 25 \\
\hline Indiana & 10 & $2.8 \%$ & 9849 & $1.6 \%$ & $6,483,802$ & $2.1 \%$ & 1.015 & 10 \\
\hline New Jersey ${ }^{3}$ & 10 & $2.8 \%$ & 19,055 & $3.2 \%$ & $8,791,894$ & $2.9 \%$ & 0.525 & 14 \\
\hline Pennsylvania & 9 & $2.5 \%$ & 25,176 & $4.2 \%$ & $12,702,379$ & $4.1 \%$ & 0.357 & 22 \\
\hline Utah & 7 & $2.0 \%$ & & & $2,763,885$ & $0.9 \%$ & & \\
\hline Virginia & 7 & $2.0 \%$ & 26,127 & $4.4 \%$ & $8,001,024$ & $2.6 \%$ & 0.268 & 27 \\
\hline Ohio & 5 & $1.4 \%$ & 32,004 & $5.3 \%$ & $11,536,504$ & $3.7 \%$ & 0.156 & 31 \\
\hline Michigan & 4 & $1.1 \%$ & 12,322 & $2.1 \%$ & $9,883,640$ & $3.2 \%$ & 0.325 & 24 \\
\hline Oklahoma & 4 & $1.1 \%$ & 10,717 & $1.8 \%$ & $3,751,351$ & $1.2 \%$ & 0.373 & 21 \\
\hline Massachusetts & 3 & $0.8 \%$ & 18,658 & $3.1 \%$ & $6,547,629$ & $2.1 \%$ & 0.161 & 30 \\
\hline Nevada & 3 & $0.8 \%$ & 3225 & $0.5 \%$ & $2,700,551$ & $0.9 \%$ & 0.930 & 11 \\
\hline South Dakota & 3 & $0.8 \%$ & 1206 & $0.2 \%$ & 814,180 & $0.3 \%$ & 2.488 & 6 \\
\hline Colorado & 2 & $0.6 \%$ & 15,884 & $2.6 \%$ & $5,029,196$ & $1.6 \%$ & 0.126 & 33 \\
\hline Iowa & 2 & $0.6 \%$ & 4646 & $0.8 \%$ & $3,046,355$ & $1.0 \%$ & 0.430 & 20 \\
\hline Mississippi & 2 & $0.6 \%$ & 3905 & $0.7 \%$ & $2,967,297$ & $1.0 \%$ & 0.512 & 16 \\
\hline Wyoming & 2 & $0.6 \%$ & 783 & $0.1 \%$ & 563,626 & $0.2 \%$ & 2.554 & 5 \\
\hline Arkansas & 1 & $0.3 \%$ & 3578 & $0.6 \%$ & $2,915,918$ & $0.9 \%$ & 0.279 & 26 \\
\hline Connecticut & 1 & $0.3 \%$ & 7139 & $1.2 \%$ & $3,574,097$ & $1.2 \%$ & 0.140 & 32 \\
\hline Idaho & 1 & $0.3 \%$ & 2799 & $0.5 \%$ & $1,567,582$ & $0.5 \%$ & 0.357 & 23 \\
\hline Kentucky & 1 & $0.3 \%$ & 8226 & $1.4 \%$ & $4,339,367$ & $1.4 \%$ & 0.122 & 34 \\
\hline Maine & 1 & $0.3 \%$ & 2054 & $0.3 \%$ & $1,328,361$ & $0.4 \%$ & 0.487 & 17 \\
\hline South Carolina & 1 & $0.3 \%$ & 5826 & $1.0 \%$ & $4,625,364$ & $1.5 \%$ & 0.172 & 29 \\
\hline West Virginia & 1 & $0.3 \%$ & 2287 & $0.4 \%$ & $1,852,994$ & $0.6 \%$ & 0.437 & 19 \\
\hline \multirow[t]{2}{*}{$\Sigma$ Other Jurisdictions ${ }^{4}$} & - & $0.0 \%$ & 74,506 & $12.4 \%$ & $42,496,258$ & $13.8 \%$ & & \\
\hline & 358 & $100 \%$ & 599,501 & $100 \%$ & $308,143,815$ & $100 \%$ & & \\
\hline
\end{tabular}

This table presents the number of violations reported by state boards that resulted in AICPA sanctions under its CPC for the period of 2008 to 2016 . Active CPA Licensees and 2010 Population data have also been provided to serve as a relative benchmark for the number of violations reported. Further, the Active CPA Licensees is used to form a per-capita measure of violations reported to demonstrate the difference between raw counts of the reporting state board and the actual rate of violations given the number of CPAs.

1 This data was not available for Utah, Delaware, or Wisconsin.

2 Calculated as the Count from the "State Board Reporting Violation" divided by the Count from the "Active CPA Licenses in 2016", then multiplied by 1000 .

${ }^{3}$ New Jersey reported the results for an audit of practitioner continuing professional education (CPE) compliance during 2013, which included 146 sanctions related to CPE adherence. These $146 \mathrm{CPE}$ sanctions are not reflected in this nor any table included in this study so as to maintain focus on the more typical trends and patterns in the nature of sanctions and reporting practices.

4 State boards with zero violations reported, as indicated in the "State Board Reporting Violation" column, were collapsed into this $\Sigma$ Other State Boards record entry and include: Alaska, Delaware, Georgia, Hawaii, Louisiana, Maryland, Minnesota, Montana, Nebraska, New Hampshire, New Mexico, North Dakota, Rhode Island, Vermont, Wisconsin.

$\mathrm{p}<0.001$, two-tailed; $\rho=0.941, \mathrm{p}<0.001$, two-tailed). Considering the relationships among our variables and the possible influences of state / state board attributes, we develop a model to explain variation in the number of violations that state boards report to the AICPA.

\subsection{Model for variation in violations reported}

The model we developed to explain variation in the number of violations that state boards report to the AICPA uses generalized least squares (GLS) and random effects, and is defined as follows (all variables are defined in Appendix A): ${ }^{26}$

\footnotetext{
${ }^{26}$ Similar to studies that have firms appear multiple times in a sample, unique state boards of accountancy can appear in each year of our sample. As such, for our primary analyses, we cluster the data by STATE and use random effects generalized least squares models (GLS) (cf. Yezegel, 2015). This approach produces standard errors that are robust to heteroscedasticity and autocorrelation, both of which are common issues with panel data such as ours (Hoechle, 2007).
} 


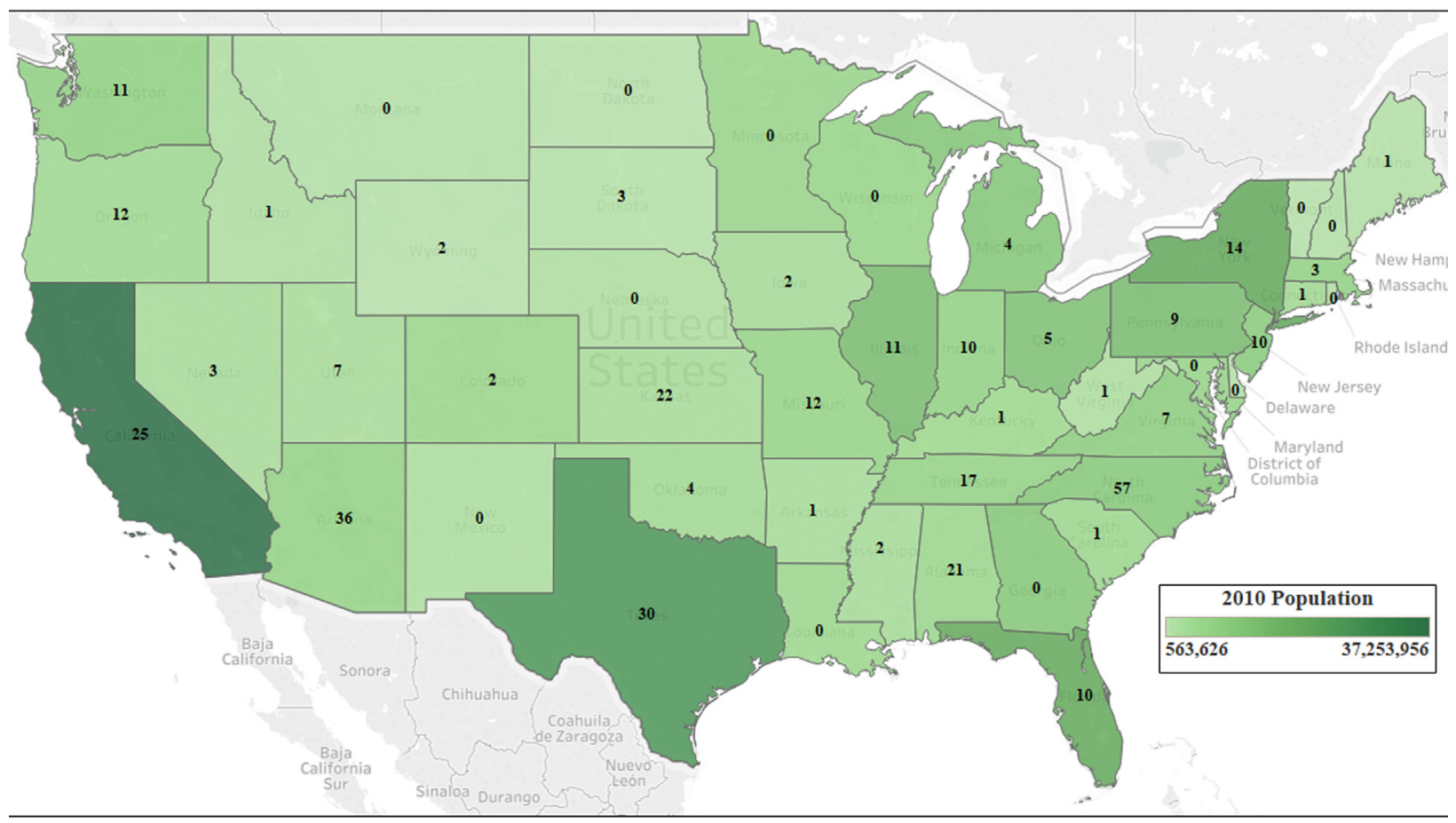

Fig. 2. U.S. Population overlaid by the Number of Violations Reported by State Boards from 2008 to 2016. This figure presents a heat map of the U.S. population as of the 2010 census (2010_POP) overlaid by the number of CPC violations reported by state boards of accountancy to the AICPA from 2008 to 2016 (VIOS_RPTD). See variables defined in Appendix A. Not pictured: Alaska and Hawaii did not have any violations reported during this period.

$$
\begin{aligned}
& \text { VIOS_RPTD } D_{s, t}=\beta_{0}+\beta_{1} C P C A D O P T_{s}+\beta_{2} \text { OPER BUD } D_{s, t}+\beta_{3} \text { ACTIVE_CPA_LIC } s+\beta_{4} \text { AICPA_OFFICE }{ }_{s}+\beta_{5} \text { WHICH_VIOS }_{s} \\
& +\beta_{6} \text { REQ_PUB_ACCT } T_{s, t}+\beta_{7} \text { PUBLIC_HQ } Q_{s, t}+\beta_{8} \text { STATE_GDP_PER_CAP } P_{s, t}+Y E A R+\varepsilon_{s, t}
\end{aligned}
$$

As shown, we analyze several possible influences on the number of CPC violations reported by state boards and cluster our panel data by STATE. Analyzed variables include: (1) whether state board (s) has fully, partially, or not adopted the AICPA CPC (CPC_ADOPT), (2) the operating budget for state board ( $s$ ) in year $(t)$ (OPER_BUD), (3) the number of active CPA licenses in state (s) in 2016 (ACTIVE_CPA_LIC), (4) whether the AICPA maintains an office in state (s) (AICPA_OFFICE), (5) the severity of violations that state board (s) directly communicates to the AICPA (WHICH_VIOS), (6) whether state board (s) requires public accounting experience for licensure, or allows for fewer years if the work experience is in public accounting (REQ PUB_ACCT), and (7) the number of public company headquarters in state $(\mathrm{s})$ for year $(\mathrm{t})\left(P U B L I C \_H Q\right)$. Further, we control for varying economic conditions with state (s) GDP per capita in year ( $\mathrm{t}$ ) (ST_GDP_PER_CAP), as well as the YEAR. Results are presented in Table 6.

Our model explains a meaningful portion of the variation in VIOS_RPTD with an $\mathrm{R}^{2}$ of 0.2492 . ACTIVE_CPA_LIC $(\mathrm{p}=0.022$, two-tailed), AICPA_OFFICE ( $\mathrm{p}=0.054$, two-tailed) and $W H I C H \_V I O S(\mathrm{p}=0.003$, two-tailed) all carry significant positive coefficients, while $S T_{-} G D P \_P E R \_C A P(\mathrm{p}=0.040$, two-tailed $)$ carries a significant negative coefficient.

A priori, it would be intuitive to expect that a fuller adoption of the AICPA's CPC would explain higher levels of state boards' reporting of violations to the AICPA (given the implicit obligation of adopters to report). However, our descriptive analyses reveal that states with partial adoption report the most violations, and thus there is not a linear relationship between CPC_ADOPT and VIOS_RPTD. Consequently, state board adoption status of the AICPA's CPC is not significant in our model. Further, the finding that the AICPA's presence leads to more reporting by state boards is revealing, in that the AICPA might have more opportunities to work closely with these state boards to promote their goal of centrally monitoring the accounting profession. Finally, it is interesting to note that the AICPA maintains offices in North Carolina, New York, New Jersey, and Washington D.C., none of which have fully adopted the AICPA's CPC (as of July 2015). ${ }^{27}$

\footnotetext{
${ }_{27}$ Our inquiries with the AICPA indicate that four states proactively report violations through direct communications to the AICPA: Kansas, Michigan, Nevada, and Wisconsin. We therefore removed these four states and re-ran our models. Our results are quantitatively and qualitatively similar.
} 


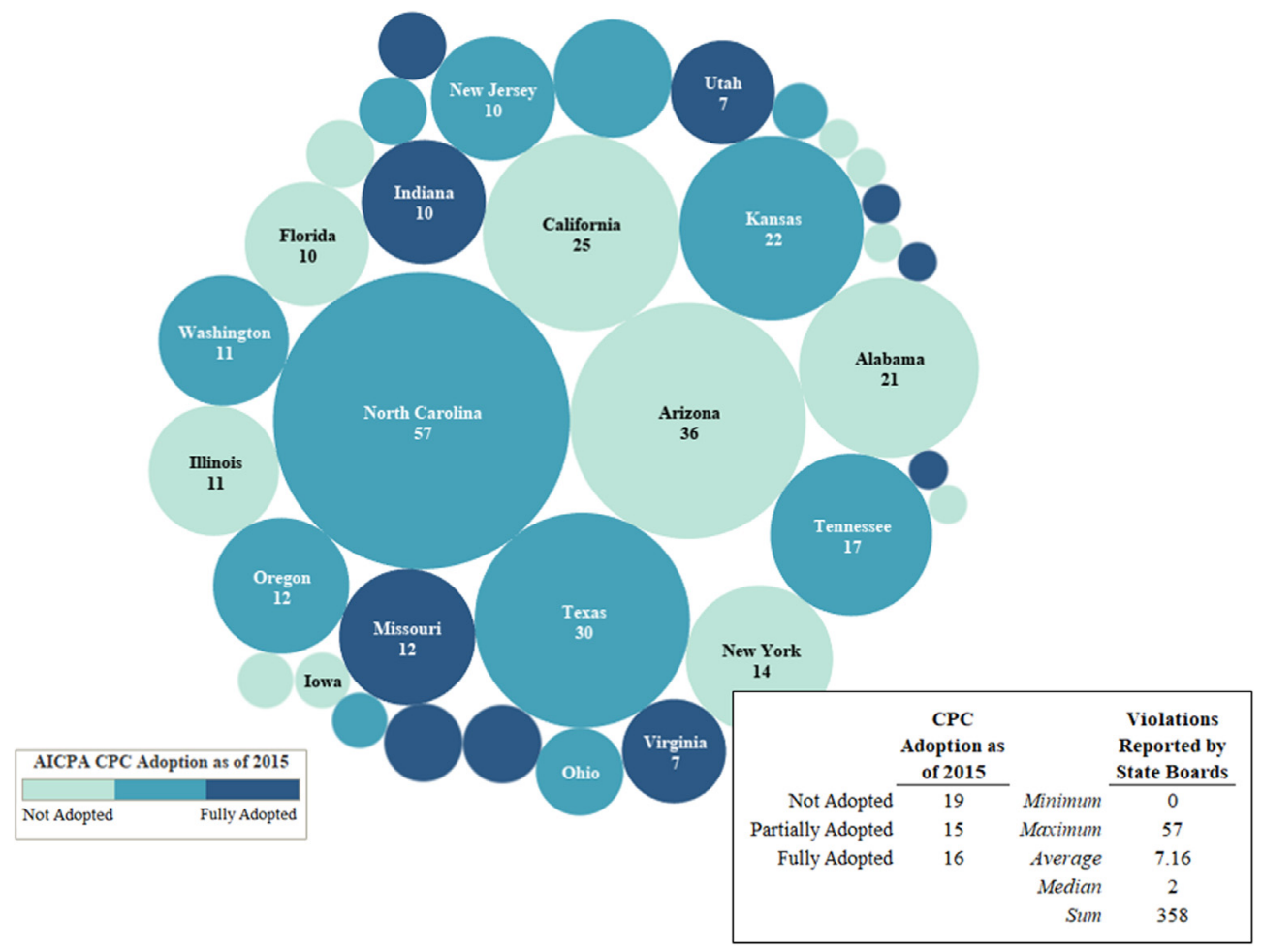

Fig. 3. Violations Reported by State Boards (2008-2016) and Level of AICPA CPC Adoption (2015). This figure presents the state board adoption status of the AICPA's CPC (CPC_ADOPT) (darker = fuller adoption) along with the number of violations reported by state boards to the AICPA from 2008 to 2016 $($ VIOS_RPTD) (larger bubbles = more violations). Numbers shown in the bubbles reflect the number of violations reported by the respective state board. See variables defined in Appendix A.

\section{Discussion and conclusion}

In this study, we examined the extent to which a state board's reporting of violations to the AICPA is associated with the degree of adoption of the AICPA's CPC. We find that a fuller adoption of the AICPA's CPC is not associated with higher levels of violation reporting, and in fact, state boards that more fully adopted the AICPA's CPC appear to be less engaged in monitoring particularly when compared to states with partial adoption. While previous studies have found that states focus on their own interests over the profession's national interests (e.g., Bishop and Tondkar, 1987; Backof and Martin, 1991), ours is the only study of which we are aware that examines the degree of state board participation as part of the AICPA's efforts to monitor the conduct of accounting professionals at the national level. Our analyses reveal variables that help explain the violation reporting practices of state boards of accountancy.

State boards of accountancy are uniquely positioned to identify and report violations of accounting professionals under the AICPA's CPC. Indeed, the AICPA loses a large amount of information and insight when data on violations are not adequately collected and reported. Such information is critical for designing continuing education programs, allocating appropriate resources to monitoring and enforcement activities, revising the CPC to address contemporary issues, modifying the CPA exam, and in serving as a centralized resource for members making ethical and technical decisions. Users of accounting information are also at risk when regulatory bodies charged with overseeing the profession do not adequately monitor accountants' conduct or routinely and openly report identified issues with the AICPA. As such, we believe the AICPA should more strongly emphasize to state boards the importance of their reporting CPC violations.

Our finding that states which fully adopt the AICPA's CPC report fewer violations than other states may lead some to question the AICPA's preeminence in setting behavioral standards for accounting professionals. Notwithstanding the AICPA's national role, perhaps states which develop their own codes of conduct or supplement that of the AICPA have more developed codes of conduct than the AICPA itself. We encourage future research that examines this issue. Further, given our challenges in collecting and analyzing state board operating budgets, we believe boards should provide greater budgetary transparency such as including amounts allocated to board activities (i.e., monitoring and enforcement of the CPC). This disclosure transparency appears appropriate considering state boards receive (partial) funding from public dollars, and in light of the impact funding has on violation reporting identified in our study. 
Table 4

Summary Descriptive Statistics Bucketed by State Board Level of AICPA CPC Adoption.

\begin{tabular}{|c|c|c|c|c|c|c|c|c|c|c|c|c|}
\hline $\begin{array}{l}\text { Level of } \\
\text { AICPA CPC } \\
\text { Adoption }\end{array}$ & $\begin{array}{l}\text { State } \\
\text { Board } \\
\text { Count }\end{array}$ & VIOS_RPTD & $\begin{array}{l}\text { Average } \\
\text { Number of } \\
\text { Violations } \\
\text { Reported }\end{array}$ & ACTIVE_CPA_LIC & $\begin{array}{l}\text { Violations per } \\
\text { Active CPA } \\
\text { License } \\
(\times 1000)\end{array}$ & RPT_FREQ & WHICH_VIOS & ETHICS_EXAM & LIC_RENEW_PRD & CPE_RPT_PRD & AVG_ETHICS_HRS & ANNUAL_FEE \\
\hline Full & 16 & 50 & 3.125 & 105,152 & 0.409 & 0.563 & 0.875 & 2.063 & 1.625 & 2.500 & 1.583 & $\$ 99.51$ \\
\hline Partial & 15 & 180 & 12.000 & 217,193 & 0.829 & 2.800 & 3.000 & 2.867 & 1.933 & 2.286 & 1.533 & $\$ 123.89$ \\
\hline Not & 19 & 128 & 6.737 & 277,156 & 0.462 & 1.895 & 2.158 & 1.474 & 1.684 & 1.947 & 1.553 & $\$ 135.42$ \\
\hline
\end{tabular}

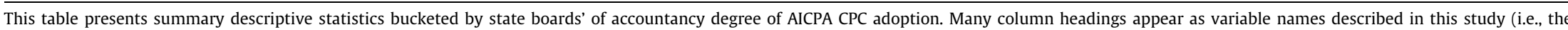
italicized headings), which are defined in Appendix A. For the remaining headings: "State Board Count" represents the number of state boards of accountancy with the respective degree of AICPA CPC adoption;

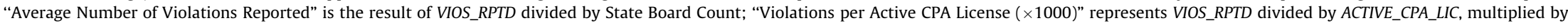

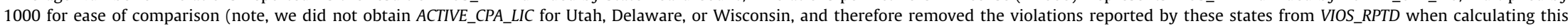

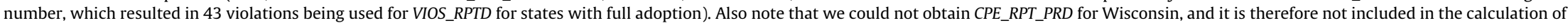
this cell for full adopters. 


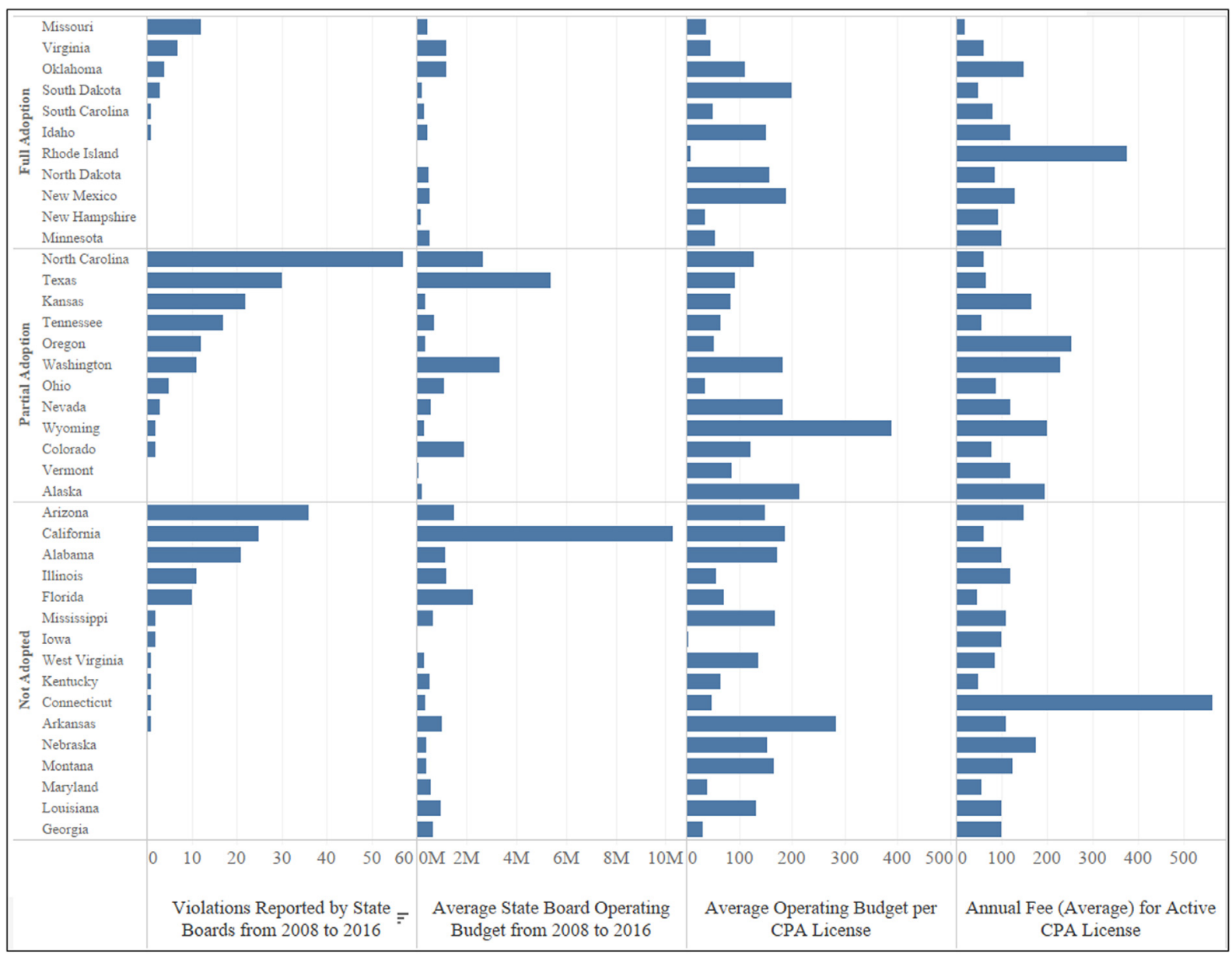

Fig. 4. AICPA CPC Adoption Status, Violations Reported, Operating Budget, and Annual CPA License Fee. This figure presents state boards bucketed by AICPA CPC adoption status (as provided in Table 1), then sorts the boards by the number of violations reported to the AICPA (VIOS_RPTD) within each adoption bucket. For states that we were able to obtain some/all operating budgets for from 2008 to 2016 (OPER_BUD before dividing by 100), we then show the average annual state board operating budget followed by the average annual operating budget per active CPA license (ACTIVE_CPA_LIC). The following states were removed from this analysis as we could not obtain any operating budget information: Delaware, Hawaii, Indiana, Maine, Massachusetts, Michigan, New Jersey, New York, Pennsylvania, Utah, and Wisconsin. Finally, we present the average annual fee for active CPA licensees (ANNUAL_FEE). See variables defined in Appendix A.

Finally, our inquiries with the state boards of accountancy reveal that violations such as those reported in this study are now commonly submitted to the Accountancy Licensee Database (ALD) as provided by NASBA. ${ }^{28}$ By submitting violations to the ALD, state boards may feel a level of reporting redundancy when notifying the AICPA of the same issues. Although the development of NASBA's ALD was intended to serve as a clearinghouse, one possible implication is reporting fragmentation of CPC violations. Thus, it is unclear whether any single authoritative body has a complete picture of trending CPA behaviors. Furthermore, the ALD is held-out as a central repository for state board reporting; however, Jenkins et al. (2018) show that a substantial portion of reported member violations originates from parties other than state boards of accountancy. Focusing only on state board reporting may limit the collection of important information. Consequently, we encourage the AICPA to work with NASBA to fully leverage its ALD in monitoring accounting professionals' conduct throughout the U.S. and as a means to identify emerging behavioral issues and trends.

More progress is needed in the central collection of CPC violations and reporting of member sanctions. While adoption of a CPC is a decision that is currently made by each state board, it is important that one body (e.g., AICPA or NASBA) has access to a complete picture of patterns of behaviors of accounting professionals across the U.S. This requires participation from many interested parties, and is only successful when these parties work in tandem towards a common goal. Without a high degree of inter-state and cross-entity efforts and cooperation, the profession is left to be reactive as opposed to proactive in addressing emerging problems.

\footnotetext{
${ }^{28}$ NASBA describes its Accountancy Licensee Database as "a central repository of current licensee and firm information. It was conceptualized to assist boards of accountancy with their regulatory mission" (NASBA, 2018b).
} 
Table 5

Pearson and Spearman Correlations.

\begin{tabular}{|c|c|c|c|c|c|c|c|c|c|c|c|c|c|c|c|c|}
\hline & (1) & $(2)$ & (3) & (4) & $(5)$ & $(6)$ & (7) & (8) & $(9)$ & $(10)$ & $(11)$ & $(12)$ & $(13)$ & $(14)$ & $(15)$ & $(16)$ \\
\hline (1) VIOS_RPTD & $\begin{array}{l}1.000 \\
459\end{array}$ & $\begin{array}{l}0.312 \\
\mathbf{0 . 0 0 0} \\
459\end{array}$ & $\begin{array}{l}0.294 \\
\mathbf{0 . 0 0 0} \\
432\end{array}$ & $\begin{array}{l}0.314 \\
\mathbf{0 . 0 0 0} \\
459\end{array}$ & $\begin{array}{l}-0.067 \\
0.151 \\
459\end{array}$ & $\begin{array}{l}0.281 \\
\mathbf{0 . 0 0 0} \\
459\end{array}$ & $\begin{array}{l}0.185 \\
\mathbf{0 . 0 0 0} \\
459\end{array}$ & $\begin{array}{l}0.221 \\
\mathbf{0 . 0 0 0} \\
459\end{array}$ & $\begin{array}{l}0.233 \\
\mathbf{0 . 0 0 0} \\
459\end{array}$ & $\begin{array}{l}-0.064 \\
0.173 \\
459\end{array}$ & $\begin{array}{l}-0.107 \\
\mathbf{0 . 0 2 2} \\
459\end{array}$ & $\begin{array}{l}0.197 \\
\mathbf{0 . 0 0 0} \\
459\end{array}$ & $\begin{array}{l}0.033 \\
0.476 \\
459\end{array}$ & $\begin{array}{l}-0.079 \\
\mathbf{0 . 0 9 2} \\
459\end{array}$ & $\begin{array}{l}0.024 \\
0.605 \\
459\end{array}$ & $\begin{array}{l}-0.074 \\
0.113 \\
459\end{array}$ \\
\hline (2) OPER_BUD & $\begin{array}{l}0.230 \\
\mathbf{0 . 0 0 0} \\
459\end{array}$ & $\begin{array}{l}1.000 \\
459\end{array}$ & $\begin{array}{l}0.639 \\
\mathbf{0 . 0 0 0} \\
432\end{array}$ & $\begin{array}{l}0.772 \\
\mathbf{0 . 0 0 0} \\
459\end{array}$ & $\begin{array}{l}-0.179 \\
\mathbf{0 . 0 0 0} \\
459\end{array}$ & $\begin{array}{l}0.307 \\
\mathbf{0 . 0 0 0} \\
459\end{array}$ & $\begin{array}{l}0.182 \\
\mathbf{0 . 0 0 0} \\
459\end{array}$ & $\begin{array}{l}-0.026 \\
0.585 \\
459\end{array}$ & $\begin{array}{l}0.663 \\
\mathbf{0 . 0 0 0} \\
459\end{array}$ & $\begin{array}{l}-0.133 \\
\mathbf{0 . 0 0 4} \\
459\end{array}$ & $\begin{array}{l}-0.147 \\
\mathbf{0 . 0 0 2} \\
459\end{array}$ & $\begin{array}{l}0.309 \\
\mathbf{0 . 0 0 0} \\
459\end{array}$ & $\begin{array}{l}0.125 \\
\mathbf{0 . 0 0 7} \\
459\end{array}$ & $\begin{array}{l}0.024 \\
0.601 \\
459\end{array}$ & $\begin{array}{l}-0.049 \\
0.295 \\
459\end{array}$ & $\begin{array}{l}-0.031 \\
0.502 \\
459\end{array}$ \\
\hline (3) ACITVE_CPA_LIC & $\begin{array}{l}0.376 \\
\mathbf{0 . 0 0 0} \\
432\end{array}$ & $\begin{array}{l}0.333 \\
\mathbf{0 . 0 0 0} \\
432\end{array}$ & $\begin{array}{l}1.000 \\
432\end{array}$ & $\begin{array}{l}0.935 \\
\mathbf{0 . 0 0 0} \\
432\end{array}$ & $\begin{array}{l}-0.178 \\
\mathbf{0 . 0 0 0} \\
432\end{array}$ & $\begin{array}{l}-0.069 \\
0.150 \\
432\end{array}$ & $\begin{array}{l}-0.166 \\
\mathbf{0 . 0 0 1} \\
432\end{array}$ & $\begin{array}{l}0.258 \\
\mathbf{0 . 0 0 0} \\
432\end{array}$ & $\begin{array}{l}0.876 \\
\mathbf{0 . 0 0 0} \\
432\end{array}$ & $\begin{array}{l}-0.099 \\
\mathbf{0 . 0 3 9} \\
432\end{array}$ & $\begin{array}{l}-0.160 \\
\mathbf{0 . 0 0 1} \\
432\end{array}$ & $\begin{array}{l}0.146 \\
\mathbf{0 . 0 0 2} \\
432\end{array}$ & $\begin{array}{l}0.068 \\
0.158 \\
432\end{array}$ & $\begin{array}{l}-0.008 \\
0.874 \\
432\end{array}$ & $\begin{array}{l}0.286 \\
\mathbf{0 . 0 0 0} \\
432\end{array}$ & $\begin{array}{l}0.023 \\
0.639 \\
432\end{array}$ \\
\hline (4) 2010_POP & $\begin{array}{l}0.400 \\
\mathbf{0 . 0 0 0} \\
459\end{array}$ & $\begin{array}{l}0.290 \\
\mathbf{0 . 0 0 0} \\
459\end{array}$ & $\begin{array}{l}0.951 \\
\mathbf{0 . 0 0 0} \\
432\end{array}$ & $\begin{array}{l}1.000 \\
459\end{array}$ & $\begin{array}{l}-0.238 \\
\mathbf{0 . 0 0 0} \\
459\end{array}$ & $\begin{array}{l}0.064 \\
0.173 \\
459\end{array}$ & $\begin{array}{l}-0.073 \\
0.120 \\
459\end{array}$ & $\begin{array}{l}0.152 \\
\mathbf{0 . 0 0 1} \\
459\end{array}$ & $\begin{array}{l}0.896 \\
\mathbf{0 . 0 0 0} \\
459\end{array}$ & $\begin{array}{l}-0.136 \\
\mathbf{0 . 0 0 3} \\
459\end{array}$ & $\begin{array}{l}-0.168 \\
\mathbf{0 . 0 0 0} \\
459\end{array}$ & $\begin{array}{l}0.117 \\
\mathbf{0 . 0 1 2} \\
459\end{array}$ & $\begin{array}{l}0.083 \\
\mathbf{0 . 0 7 6} \\
459\end{array}$ & $\begin{array}{l}-0.031 \\
0.512 \\
459\end{array}$ & $\begin{array}{l}0.229 \\
\mathbf{0 . 0 0 0} \\
459\end{array}$ & $\begin{array}{l}-0.045 \\
0.338 \\
459\end{array}$ \\
\hline (5) CPC_ADOPT & $\begin{array}{l}-0.043 \\
0.353 \\
459\end{array}$ & $\begin{array}{l}-0.175 \\
\mathbf{0 . 0 0 0} \\
459\end{array}$ & $\begin{array}{l}-0.114 \\
\mathbf{0 . 0 1 8} \\
432\end{array}$ & $\begin{array}{l}-0.199 \\
\mathbf{0 . 0 0 0} \\
459\end{array}$ & $\begin{array}{l}1.000 \\
459\end{array}$ & $\begin{array}{l}-0.150 \\
\mathbf{0 . 0 0 1} \\
459\end{array}$ & $\begin{array}{l}-0.189 \\
\mathbf{0 . 0 0 0} \\
459\end{array}$ & $\begin{array}{l}-0.147 \\
\mathbf{0 . 0 0 2} \\
459\end{array}$ & $\begin{array}{l}-0.292 \\
\mathbf{0 . 0 0 0} \\
459\end{array}$ & $\begin{array}{l}-0.143 \\
\mathbf{0 . 0 0 2} \\
459\end{array}$ & $\begin{array}{l}0.055 \\
0.241 \\
459\end{array}$ & $\begin{array}{l}0.206 \\
\mathbf{0 . 0 0 0} \\
459\end{array}$ & $\begin{array}{l}0.003 \\
0.947 \\
459\end{array}$ & $\begin{array}{l}0.300 \\
\mathbf{0 . 0 0 0} \\
459\end{array}$ & $\begin{array}{l}-0.034 \\
0.472 \\
459\end{array}$ & $\begin{array}{l}-0.147 \\
\mathbf{0 . 0 0 2} \\
459\end{array}$ \\
\hline (6) WHICH_VIOS & $\begin{array}{l}0.203 \\
\mathbf{0 . 0 0 0} \\
459\end{array}$ & $\begin{array}{l}0.343 \\
\mathbf{0 . 0 0 0} \\
459\end{array}$ & $\begin{array}{l}-0.132 \\
\mathbf{0 . 0 0 6} \\
432\end{array}$ & $\begin{array}{l}-0.060 \\
0.197 \\
459\end{array}$ & $\begin{array}{l}-0.187 \\
\mathbf{0 . 0 0 0} \\
459\end{array}$ & $\begin{array}{l}1.000 \\
459\end{array}$ & $\begin{array}{l}0.799 \\
\mathbf{0 . 0 0 0} \\
459\end{array}$ & $\begin{array}{l}-0.021 \\
0.660 \\
459\end{array}$ & $\begin{array}{l}0.011 \\
0.806 \\
459\end{array}$ & $\begin{array}{l}-0.032 \\
0.491 \\
459\end{array}$ & $\begin{array}{l}0.143 \\
\mathbf{0 . 0 0 2} \\
459\end{array}$ & $\begin{array}{l}0.211 \\
\mathbf{0 . 0 0 0} \\
459\end{array}$ & $\begin{array}{l}-0.029 \\
0.532 \\
459\end{array}$ & $\begin{array}{l}-0.204 \\
\mathbf{0 . 0 0 0} \\
459\end{array}$ & $\begin{array}{l}-0.134 \\
\mathbf{0 . 0 0 4} \\
459\end{array}$ & $\begin{array}{l}-0.219 \\
\mathbf{0 . 0 0 0} \\
459\end{array}$ \\
\hline (7) RPT_FREQ & $\begin{array}{l}0.135 \\
\mathbf{0 . 0 0 4} \\
459\end{array}$ & $\begin{array}{l}0.302 \\
\mathbf{0 . 0 0 0} \\
459\end{array}$ & $\begin{array}{l}-0.191 \\
\mathbf{0 . 0 0 0} \\
432\end{array}$ & $\begin{array}{l}-0.127 \\
\mathbf{0 . 0 0 7} \\
459\end{array}$ & $\begin{array}{l}-0.199 \\
\mathbf{0 . 0 0 0} \\
459\end{array}$ & $\begin{array}{l}0.941 \\
\mathbf{0 . 0 0 0} \\
459\end{array}$ & $\begin{array}{l}1.000 \\
459\end{array}$ & $\begin{array}{l}-0.024 \\
0.609 \\
459\end{array}$ & $\begin{array}{l}-0.095 \\
\mathbf{0 . 0 4 1} \\
459\end{array}$ & $\begin{array}{l}-0.042 \\
0.365 \\
459\end{array}$ & $\begin{array}{l}0.158 \\
\mathbf{0 . 0 0 1} \\
459\end{array}$ & $\begin{array}{l}0.176 \\
\mathbf{0 . 0 0 0} \\
459\end{array}$ & $\begin{array}{l}-0.046 \\
0.330 \\
459\end{array}$ & $\begin{array}{l}-0.127 \\
\mathbf{0 . 0 0 6} \\
459\end{array}$ & $\begin{array}{l}-0.285 \\
\mathbf{0 . 0 0 0} \\
459\end{array}$ & $\begin{array}{l}-0.203 \\
\mathbf{0 . 0 0 0} \\
459\end{array}$ \\
\hline (8) AICPA_OFFICE & $\begin{array}{l}0.200 \\
\mathbf{0 . 0 0 0} \\
459\end{array}$ & $\begin{array}{l}-0.132 \\
\mathbf{0 . 0 0 5} \\
459\end{array}$ & $\begin{array}{l}0.207 \\
\mathbf{0 . 0 0 0} \\
432\end{array}$ & $\begin{array}{l}0.149 \\
\mathbf{0 . 0 0 1} \\
459\end{array}$ & $\begin{array}{l}-0.142 \\
\mathbf{0 . 0 0 2} \\
459\end{array}$ & $\begin{array}{l}-0.046 \\
0.320 \\
459\end{array}$ & $\begin{array}{l}-0.041 \\
0.382 \\
459\end{array}$ & $\begin{array}{l}1.000 \\
459\end{array}$ & $\begin{array}{l}0.226 \\
\mathbf{0 . 0 0 0} \\
459\end{array}$ & $\begin{array}{l}-0.020 \\
0.674 \\
459\end{array}$ & $\begin{array}{l}-0.003 \\
0.944 \\
459\end{array}$ & $\begin{array}{l}-0.008 \\
0.870 \\
459\end{array}$ & $\begin{array}{l}0.041 \\
0.379 \\
459\end{array}$ & $\begin{array}{l}-0.164 \\
\mathbf{0 . 0 0 0} \\
459\end{array}$ & $\begin{array}{l}0.208 \\
\mathbf{0 . 0 0 0} \\
459\end{array}$ & $\begin{array}{l}0.504 \\
\mathbf{0 . 0 0 0} \\
459\end{array}$ \\
\hline (9) PUBLIC_HQ & $\begin{array}{l}0.333 \\
\mathbf{0 . 0 0 0} \\
459\end{array}$ & $\begin{array}{l}0.217 \\
\mathbf{0 . 0 0 0} \\
459\end{array}$ & $\begin{array}{l}0.930 \\
\mathbf{0 . 0 0 0} \\
432\end{array}$ & $\begin{array}{l}0.878 \\
\mathbf{0 . 0 0 0} \\
459\end{array}$ & $\begin{array}{l}-0.200 \\
\mathbf{0 . 0 0 0} \\
459\end{array}$ & $\begin{array}{l}-0.123 \\
\mathbf{0 . 0 0 9} \\
459\end{array}$ & $\begin{array}{l}-0.171 \\
\mathbf{0 . 0 0 0} \\
459\end{array}$ & $\begin{array}{l}0.209 \\
\mathbf{0 . 0 0 0} \\
459\end{array}$ & $\begin{array}{l}1.000 \\
459\end{array}$ & $\begin{array}{l}-0.019 \\
0.681 \\
459\end{array}$ & $\begin{array}{l}-0.119 \\
\mathbf{0 . 0 1 1} \\
459\end{array}$ & $\begin{array}{l}0.100 \\
\mathbf{0 . 0 3 3} \\
459\end{array}$ & $\begin{array}{l}0.103 \\
\mathbf{0 . 0 2 8} \\
459\end{array}$ & $\begin{array}{l}-0.039 \\
0.399 \\
459\end{array}$ & $\begin{array}{l}0.293 \\
\mathbf{0 . 0 0 0} \\
459\end{array}$ & $\begin{array}{l}0.094 \\
\mathbf{0 . 0 4 3} \\
459\end{array}$ \\
\hline (10) ANNUAL_FEE & $\begin{array}{l}-0.078 \\
\mathbf{0 . 0 9 7} \\
459\end{array}$ & $\begin{array}{l}-0.008 \\
0.862 \\
459\end{array}$ & $\begin{array}{l}-0.318 \\
\mathbf{0 . 0 0 0} \\
432\end{array}$ & $\begin{array}{l}-0.255 \\
\mathbf{0 . 0 0 0} \\
459\end{array}$ & $\begin{array}{l}-0.167 \\
\mathbf{0 . 0 0 0} \\
459\end{array}$ & $\begin{array}{l}0.136 \\
\mathbf{0 . 0 0 4} \\
459\end{array}$ & $\begin{array}{l}0.135 \\
\mathbf{0 . 0 0 4} \\
459\end{array}$ & $\begin{array}{l}-0.159 \\
\mathbf{0 . 0 0 1} \\
459\end{array}$ & $\begin{array}{l}-0.256 \\
\mathbf{0 . 0 0 0} \\
459\end{array}$ & $\begin{array}{l}1.000 \\
459\end{array}$ & $\begin{array}{l}-0.029 \\
0.539 \\
459\end{array}$ & $\begin{array}{l}0.079 \\
\mathbf{0 . 0 8 9} \\
459\end{array}$ & $\begin{array}{l}0.030 \\
0.520 \\
459\end{array}$ & $\begin{array}{l}-0.127 \\
\mathbf{0 . 0 0 6} \\
459\end{array}$ & $\begin{array}{l}0.077 \\
0.100 \\
459\end{array}$ & $\begin{array}{l}0.085 \\
\mathbf{0 . 0 6 8} \\
459\end{array}$ \\
\hline (11) REQ_PUB_ACCT & $\begin{array}{l}-0.080 \\
\mathbf{0 . 0 8 8} \\
459\end{array}$ & $\begin{array}{l}-0.107 \\
\mathbf{0 . 0 2 2} \\
459\end{array}$ & $\begin{array}{l}-0.208 \\
\mathbf{0 . 0 0 0} \\
432\end{array}$ & $\begin{array}{l}-0.153 \\
\mathbf{0 . 0 0 1} \\
459\end{array}$ & $\begin{array}{l}0.065 \\
0.164 \\
459\end{array}$ & $\begin{array}{l}0.138 \\
\mathbf{0 . 0 0 3} \\
459\end{array}$ & $\begin{array}{l}0.162 \\
\mathbf{0 . 0 0 0} \\
459\end{array}$ & $\begin{array}{l}-0.003 \\
0.944 \\
459\end{array}$ & $\begin{array}{l}-0.142 \\
\mathbf{0 . 0 0 2} \\
459\end{array}$ & $\begin{array}{l}0.087 \\
\mathbf{0 . 0 6 2} \\
459\end{array}$ & $\begin{array}{l}1.000 \\
459\end{array}$ & $\begin{array}{l}0.225 \\
\mathbf{0 . 0 0 0} \\
459\end{array}$ & $\begin{array}{l}-0.126 \\
\mathbf{0 . 0 0 7} \\
459\end{array}$ & $\begin{array}{l}-0.195 \\
\mathbf{0 . 0 0 0} \\
459\end{array}$ & $\begin{array}{l}-0.044 \\
0.352 \\
459\end{array}$ & $\begin{array}{l}-0.029 \\
0.533 \\
459\end{array}$ \\
\hline (12) ETHICS_EXAM & $\begin{array}{l}0.192 \\
\mathbf{0 . 0 0 0} \\
459\end{array}$ & $\begin{array}{l}0.312 \\
\mathbf{0 . 0 0 0} \\
459\end{array}$ & $\begin{array}{l}0.169 \\
\mathbf{0 . 0 0 0} \\
432\end{array}$ & $\begin{array}{l}0.126 \\
\mathbf{0 . 0 0 7} \\
459\end{array}$ & $\begin{array}{l}0.184 \\
\mathbf{0 . 0 0 0} \\
459\end{array}$ & $\begin{array}{l}0.170 \\
\mathbf{0 . 0 0 0} \\
459\end{array}$ & $\begin{array}{l}0.138 \\
\mathbf{0 . 0 0 3} \\
459\end{array}$ & $\begin{array}{l}0.053 \\
0.254 \\
459\end{array}$ & $\begin{array}{l}0.174 \\
\mathbf{0 . 0 0 0} \\
459\end{array}$ & $\begin{array}{l}-0.004 \\
0.937 \\
459\end{array}$ & $\begin{array}{l}0.215 \\
\mathbf{0 . 0 0 0} \\
459\end{array}$ & $\begin{array}{l}1.000 \\
459\end{array}$ & $\begin{array}{l}-0.127 \\
\mathbf{0 . 0 0 6} \\
459\end{array}$ & $\begin{array}{l}0.184 \\
\mathbf{0 . 0 0 0} \\
459\end{array}$ & $\begin{array}{l}-0.065 \\
0.168 \\
459\end{array}$ & $\begin{array}{l}-0.041 \\
0.386 \\
459\end{array}$ \\
\hline (13) AVG_ETHICS_HRS & $\begin{array}{l}-0.010 \\
0.823 \\
459\end{array}$ & $\begin{array}{l}0.046 \\
0.330 \\
459\end{array}$ & $\begin{array}{l}0.049 \\
0.305 \\
432\end{array}$ & $\begin{array}{l}0.029 \\
0.531 \\
459\end{array}$ & $\begin{array}{l}0.075 \\
0.111 \\
459\end{array}$ & $\begin{array}{l}-0.032 \\
0.489 \\
459\end{array}$ & $\begin{array}{l}-0.054 \\
0.245 \\
459\end{array}$ & $\begin{array}{l}0.032 \\
0.497 \\
459\end{array}$ & $\begin{array}{l}0.157 \\
\mathbf{0 . 0 0 1} \\
459\end{array}$ & $\begin{array}{l}0.027 \\
0.564 \\
459\end{array}$ & $\begin{array}{l}-0.095 \\
\mathbf{0 . 0 4 2} \\
459\end{array}$ & $\begin{array}{l}-0.069 \\
0.142 \\
459\end{array}$ & $\begin{array}{l}1.000 \\
459\end{array}$ & $\begin{array}{l}-0.033 \\
0.478 \\
459\end{array}$ & $\begin{array}{l}-0.019 \\
0.690 \\
459\end{array}$ & $\begin{array}{l}0.059 \\
0.211 \\
459\end{array}$ \\
\hline (14) CPE_RPT_PRD & $\begin{array}{l}-0.052 \\
0.265 \\
459\end{array}$ & $\begin{array}{l}0.042 \\
0.367 \\
459\end{array}$ & $\begin{array}{l}-0.007 \\
0.882 \\
432\end{array}$ & $\begin{array}{l}-0.065 \\
0.162 \\
459\end{array}$ & $\begin{array}{l}0.330 \\
\mathbf{0 . 0 0 0} \\
459\end{array}$ & $\begin{array}{l}-0.209 \\
\mathbf{0 . 0 0 0} \\
459\end{array}$ & $\begin{array}{l}-0.161 \\
\mathbf{0 . 0 0 1} \\
459\end{array}$ & $\begin{array}{l}-0.161 \\
\mathbf{0 . 0 0 1} \\
459\end{array}$ & $\begin{array}{l}-0.075 \\
0.107 \\
459\end{array}$ & $\begin{array}{l}-0.049 \\
0.295 \\
459\end{array}$ & $\begin{array}{l}-0.157 \\
\mathbf{0 . 0 0 1} \\
459\end{array}$ & $\begin{array}{l}0.213 \\
\mathbf{0 . 0 0 0} \\
459\end{array}$ & $\begin{array}{l}-0.113 \\
\mathbf{0 . 0 1 5} \\
459\end{array}$ & 1.000 & $\begin{array}{l}0.156 \\
\mathbf{0 . 0 0 1} \\
459\end{array}$ & $\begin{array}{l}0.047 \\
0.318 \\
459\end{array}$ \\
\hline
\end{tabular}




\begin{tabular}{|c|c|c|c|c|c|c|c|c|c|c|c|c|c|c|c|c|}
\hline & $(1)$ & $(2)$ & (3) & $(4)$ & (5) & (6) & $(7)$ & $(8)$ & (9) & $(10)$ & $(11)$ & $(12)$ & (13) & $(14)$ & (15) & $(16)$ \\
\hline \multirow{3}{*}{ (15) LIC_RENEW_PRD } & 0.100 & -0.266 & 0.326 & 0.309 & -0.050 & -0.159 & -0.248 & 0.186 & 0.378 & -0.028 & -0.048 & -0.051 & -0.005 & 0.106 & 1.000 & 0.167 \\
\hline & 0.032 & 0.000 & 0.000 & 0.000 & 0.283 & 0.001 & 0.000 & 0.000 & 0.000 & 0.550 & 0.303 & 0.273 & 0.919 & 0.023 & & 0.000 \\
\hline & 459 & 459 & 432 & 459 & 459 & 459 & 459 & 459 & 459 & 459 & 459 & 459 & 459 & 459 & 459 & 459 \\
\hline \multirow[t]{3}{*}{ (16) ST_GDP_PER_CAP } & -0.023 & -0.172 & 0.154 & -0.001 & -0.051 & -0.305 & -0.284 & 0.277 & 0.282 & 0.115 & 0.014 & 0.256 & 0.086 & 0.202 & 0.315 & 1.000 \\
\hline & 0.617 & 0.000 & 0.001 & 0.976 & 0.272 & 0.000 & 0.000 & 0.000 & 0.000 & 0.013 & 0.757 & 0.000 & 0.066 & 0.000 & 0.000 & \\
\hline & 459 & 459 & 432 & 459 & 459 & 459 & 459 & 459 & 459 & 459 & 459 & 459 & 459 & 459 & 459 & 459 \\
\hline
\end{tabular}

Reported: Pearson (top-right) and Spearman (bottom-left) correlations, p-values (two-tailed), and sample size. Variables are defined in Appendix A. 
Table 6

Multivariate results.

\begin{tabular}{llll}
\hline & Coefficient & Z-Stat & P-Value (2-tailed) \\
\hline VIOS_RPTD & & & \\
CPC_ADOPT & 0.05584 & 0.43 & 0.668 \\
OPER_BUD & 0.00001 & 0.93 & 0.351 \\
ACTIVE_CPA_LIC & 0.00004 & 2.29 & 0.022 \\
AICPA_OFFICE & 1.93465 & 1.93 & 0.054 \\
WHICH_VIOS & 0.16587 & 2.98 & 0.003 \\
REQ_PUB_ACCT & $(0.46603)$ & $(1.80)$ & 0.071 \\
PUBLIC_HQ & $(0.00098)$ & $(0.93)$ & 0.352 \\
STATE_GDP_PER_CAP & $(0.00002)$ & $(2.06)$ & 0.040 \\
YEAR & 0.87686 & 2.86 & 0.004 \\
Intercept & $(175.710)$ & $(2.86)$ & 0.004 \\
Panel Variable & State & & \\
Observations & 432 & & \\
R $^{2}$ & 0.2492 & & \\
\hline
\end{tabular}

The model presented uses generalized least squares (GLS) with random effects, and has STATE set as the panel variable. Defining the variable as such helps address concerns of autocorrelation with panel data. The model also incorporates standard errors that are robust to heteroscedasticity and autocorrelation (Hoechle, 2007). Variables are defined in Appendix A.

\section{Data availability}

Data used in this study are available upon request and by permission granted by the AICPA.

\section{Funding}

This research did not receive any specific grant from funding agencies in the public, commercial, or not-for-profit sectors.

\section{Declaration of Competing Interest}

None.

\section{Acknowledgements}

The authors would like to thank participants at the 2015 and 2017 AAA Annual Meetings, the 2017 AAA Ethics Research Symposium, and workshops at Radford University, Towson University, and Kennesaw State University. The authors would also like to thank practitioners participating in the Accounting and Auditing Symposium at KSU. Finally, we thank our contacts at the AICPA for generously providing data used in this study as well as responding to our various questions.

\section{Appendix A. Variable definitions}

\begin{tabular}{|c|c|}
\hline Variable & Definition \\
\hline VIOS_RPTD & $\begin{array}{l}\text { The number of violations reported by a state board of accountancy to the AICPA that lead to sanctions } \\
\text { under the AICPA CPC in year }(t) \text { and state }(s) \text {. }\end{array}$ \\
\hline OPER_BUD & The state board of accountancy operating budget divided by 100 for year $(\mathrm{t})$ and state $(\mathrm{s})$. \\
\hline ACITVE_CPA_LIC & Active CPA licenses in state (s) during the year 2016 (per NASBA). \\
\hline $2010 \_P O P$ & The populations of state (s) per the 2010 U.S. Census. \\
\hline CPC_ADOPT & $\begin{array}{l}\text { Ordinal variable for whether state (s) has not adopted (0), partially adopted ( } 1 \text { ), or fully adopted (2) } \\
\text { the AICPA CPC as their own. }\end{array}$ \\
\hline WHICH_VIOS & $\begin{array}{l}\text { Ordinal variable for which violations state board (s) claims to directly communicate to the AICPA, as } \\
\text { detailed in Table 2: (8) All, (7) Comm.Rev/Sus, (6) Comm > Admin, (5) Comm > NoEdu, (4) Comm. } \\
\text { Serious, (3) Comm.Suspen, (2) Comm.Disc, (1) Unknown, and (0) Do Not Directly Communicate. }\end{array}$ \\
\hline RPT_FREQ & $\begin{array}{l}\text { Ordinal variable for the frequency at which state board (s) claims to directly communicate violations } \\
\text { to the AICPA, as detailed in Table 2: (6) As Occur, (5) Monthly, (4) Bi-Monthly, (3) Quarterly, (2) Every } \\
\text { Other Year, (1) Every Three Years, and (0) Do Not Report. }\end{array}$ \\
\hline AICPA_OFFICE & $\begin{array}{l}\text { Dummy variable that indicates whether the AICPA has an office in state }(s)(0=\text { No, } 1=\text { Yes }) \text {. The } \\
\text { AICPA maintains offices in North Carolina, New Jersey, New York, and Washington D.C. }\end{array}$ \\
\hline
\end{tabular}


Appendix A (continued)

\begin{tabular}{|c|c|}
\hline Variable & Definition \\
\hline PUBLIC_HQ & The number of public companies headquartered in state $(\mathrm{s})$ in year $(\mathrm{t})$. \\
\hline ANNUAL_FEE & $\begin{array}{l}\text { Annual CPA licensing fee in state (s) as of the year 2019. If a state charges the licensing fee for } \\
\text { multiple years at a time, this number represents the annual average fee. }\end{array}$ \\
\hline REQ PUB_ACCT & $\begin{array}{l}\text { Dummy variable for whether state }(s) \text { requires public accounting experience or allows for fewer } \\
\text { years of experience if it is gained in public accounting }(0=\text { No, } 1=\text { Yes }) \text { as of the year } 2017 \text {. }\end{array}$ \\
\hline ETHICS_EXAM & $\begin{array}{l}\text { Ordinal variable for the level of control a state board asserts over the ethics exam content that the } \\
\text { board of accountancy in state (s) requires for new CPAs: (4) state-specific ethics exam, ( } 3 \text { ) AICPA } \\
\text { Ethics Exam, (2) AICPA Ethics Exam or an exam approved by the state board, (1) an ethics exam } \\
\text { approved by the state board, or (0) no ethics exam is required. }\end{array}$ \\
\hline AVG_ETHICS_HRS & Average number of ethics CPE hours required by state (s) as of the year 2017. \\
\hline$C P E \_R P T \_P R D$ & The number of years state (s) allows between reporting CPEs, as of the year 2017 . \\
\hline LIC_RENEW_PRD & The number of years state (s) allows between CPA license renewals, as of the year 2017. \\
\hline ST_GDP_PER_CAP & Gross domestic product per capita for state $(\mathrm{s})$ in year $(\mathrm{t})$. \\
\hline YEAR & Year from the sample period. \\
\hline STATE & State board associated with the data record. \\
\hline
\end{tabular}

\section{Appendix B. Supplementary material}

Supplementary data to this article can be found online at https://doi.org/10.1016/j.jaccpubpol.2020.106742.

\section{References}

Adam, A.M., Rachman-Moore, D., 2004. The methods used to implement an ethical code of conduct and employee attitudes. J. Bus. Ethics 54, 225-244. American Institute of Certified Public Accountants (AICPA), 2014. AICPA-NASBA Uniform Accountancy Act. Available at: <http://www.aicpa.org/Advocacy/ State/DownloadableDocuments/UAASeventhEdition.pdf>.

American Institute of Certified Public Accountants (AICPA), 2015a. The AUCPA Code of Professional Conduct: Protecting the Public Interest. Available at: <https://www.aicpa.org/Advocacy/State/DownloadableDocuments/Code-of-Conduct-Advocacy-Page.pdf>.

American Institute of Certified Public Accountants (AICPA), 2015b. Code of Professional Conduct Adoption. Available at: <http://www.aicpa.org/Advocacy/ State/DownloadableDocuments/Code-of-Conduct-Map.pdf>.

American Institute of Certified Public Accountants (AICPA), 2016. AICPA Code of Professional Conduct. Available at: <https://www.aicpa.org/content/dam/ aicpa/research/standards/codeofconduct/downloadabledocuments/2014december15contentasof2016august31codeofconduct.pdf>.

American Institute of Certified Public Accountants (AICPA), 2018a. About the AICPA. Available at: <http://www.aicpa.org/About.html> (last accessed August 2018).

American Institute of Certified Public Accountants (AICPA), 2018b. Frequently Asked Questions About the AICPA. Available at: <https://www.aicpa.org/ about/faqs.html> (last accessed August 2018)

Armitage, J., Moriarity, S., 2016. An examination of AICPA disciplinary actions: 1980-2014. Curr. Issues Audit. 10, A1-A13.

Backof, J., Martin Jr., C., 1991. Historical perspectives: Development of the codes of ethics in the legal, medical and accounting professions. J. Bus. Ethics 19, 99-110.

Badawi, I., Rude, J., 1995. AICPA CPC and disciplinary actions in ethics cases against CPAs. Conference Proceedings of the International Conference Promoting Business Ethics. New York City, N.Y., November 2-4, 316-323.

Badawi, I., Rude, J., 1997. A cross- state analysis of disciplinary actions by the AICPA in ethics cases. Conference Proceedings of the American Academy of Accounting and Finance. New Orleans, LA, December 10-12, 371-377.

Badawi, I., 2002. Accounting codes of conduct, violations and disciplinary actions. Rev. Bus. 23, $72-76$.

Bédard, J., 2001. The disciplinary process of the accounting profession: protecting the public or the profession? The Quebec experience. J. Account. Public Policy 20, 399-437.

Bishop, A., Tondkar, R., 1987. Development of a professional code of ethics. J. Account. 163, 97-100.

Canning, M., O’Dwyer, B., 2001. Professional accounting bodies' disciplinary procedures: accountable, transparent and in the public interest?. Eur. Account. Rev. 10, 725-749.

Canning, M., O'Dwyer, B., 2003. A critique of the descriptive power of the private interest model of professional accounting ethics: an examination over time in the Irish context. Account. Audit. Account. J. 16, 159-185.

Cardona, R.J., Rezaee, Z., Rivera-Ortiz, W., Vega-Vilca, J.C., 2019. Regulatory enforcement of accounting ethics in Puerto Rico. J. Bus. Ethics. https://doi.org/ 10.1007/s10551-019-04137-4.

Clements, C., Neill, J.D., Stovall, O.S., 2009. An analysis of international accounting codes of conduct. J. Bus. Ethics 87, $173-183$.

Falk, A., Kosfeld, M., 2006. The hidden costs of control. The Am. Econ. Rev. 96 (5), 1611-1630.

Hoechle, D., 2007. Robust standard errors for panel regressions with cross-sectional dependence. Stata J. 7, 281.

Jenkins, J.G., Popova, V., Sheldon, M.D., 2018. In support of public or private interests? An examination of sanctions imposed under the AICPA Code of Professional Conduct. J. Bus. Ethics 152, 523-549.

Krom, C., 2019. Disciplinary actions by state professional licensing boards: Are they fair?. J. Bus. Ethics 158, $567-583$.

Loeb, S.E., 1972. Enforcement of the code of ethics: A Survey. Account. Rev. 47, 1-10.

Loeb, S.E., 1984. Codes of ethics and self-regulation for non-public accountants: A public policy perspective. J. Account. Public Policy 3, 1-8.

Loeb, S.E., 1986. Accounting regulation: some further research questions. J. Account. Public Policy 5, 1-4.

Moriarity, S., 2000. Trends in ethical sanctions within the accounting profession. Account. Horiz. 14, 427-439.

National Association of State Boards of Accountancy (NASBA), 2018a. Boards of Accountancy. Available at: <https://nasba.org/stateboards/> (last accessed August 2018).

National Association of State Boards of Accountancy (NASBA), 2018b. Accountancy Licensee Database. Available at: <https://nasba.org/mc/resources/ald/> 
Parker, L.D., 1987. An historical analysis of ethical pronouncements and debate in the Australian accounting profession. Abacus 23, $122-138$.

Parker, L.D., 1994. Professional accounting body ethics: in search of the private interest. Account. Organ. Soc. 19, 507-525.

Schaefer, J., Welker, R.B., 1994. Distinguishing characteristics of certified public accountants disciplined for unprofessional behavior. J. Account. Public Policy 13, 97-119.

Tidrick, D., 1992. Disciplinary actions by the AICPA against individual members, 1980-1990. Res. Account. Regulation 6, $163-177$.

United States Census Bureau, 2010. 2010 Census Data. Available at: <https://www.census.gov/programs-surveys/decennial-census/data/datasets.2010. html>.

Yezegel, A., 2015. Why do analysts revise their stock recommendations after earnings announcements?. J. Account. Economics 59, $163-181$. 